\title{
A Numerical Taxonomic Study of Coryneform and Related Bacteria
}

\author{
By DOROTHY JONES \\ M.R.C. Microbial Systematics Unit, School of Biological Sciences, \\ The University, Leicester $L E$ I $7 R H$
}

(Received 23 May 1974; revised 14 August 1974)

\begin{abstract}
SUMMARY
Two hundred and thirty-three strains of coryneform bacteria, including representatives of the genera Arthrobacter, Brevibacterium, Cellulomonas, Corynebacterium, Erysipelothrix, Jensenia, Kurthia, Listeria, Microbacterium, Mycobacterium, Nocardia and Propionibacterium and other related bacteria, were studied using 173 morphological, physiological and biochemical tests. The bacteria were grown on a soil extract medium which allowed growth of all the strains, and all were incubated at $30{ }^{\circ} \mathrm{C}$. The results were subjected to computer analysis. The majority of the strains grouped into eight main clusters representing: (A) Lactobacillus, Listeria, Microbacterium thermosphactum and Streptococcus faecalis; (B) Erysipelothrix and Streptococcus pyogenes; (C) animal corynebacteria and Microbacterium flavum; (D) Cellulomonas and related bacteria; (E) Propionibacterium; (F) Arthrobacter, Brevibacterium, Kurthia and Mycobacterium rhodochrous; (G) plant pathogenic corynebacteria; $(\mathbf{H})$ Nocardia. Based on these clusters, several recommendations are made regarding the classification of the coryneform area. (i) The members of clusters A and B at present placed in the Corynebacteriaceae would seem better moved to the Lactobacillaceae. (ii) The genus Corynebacterium would best be retained for the type species $C$. diphtheriae, closely related animal corynebacteria and Micro. flavum. (iii) Cellulomonas and Propionibacterium are distinct taxa more closely related to Corynebacterium than to either Arthrobacter or Lactobacillus. (iv) Clusters $\mathrm{F}$ and $\mathrm{G}$ are evidently heterogeneous. In particular the positions of Kurthia and the plant pathogenic corynebacteria are unclear. Arthrobacter is a large loose taxon and it is premature to decide on its taxonomic rank. The genus Brevibacterium should be retained for $B$. linens and closely related strains. (v) The cellulolytic forms of Nocardia should be removed from the genus; they are however quite distinct from Cellulomonas.
\end{abstract}

\section{INTRODUCTION}

The term coryneform, originally used to describe the club-shaped or wedge-shaped cells of Corynebacteria diphtheriae and related animal parasites, is now widely used to describe Gram-positive, non-mycelial, non-sporing bacteria which exhibit a pleomorphic morphology (Jensen, I952; Veldkamp, I970).

The definitions of the genera commonly referred to as coryneform (Corynebacterium, Microbacterium, Cellulomonas and Arthrobacter (Jensen, 1952) are equivocal because they are based almost entirely on microscopic appearance and staining characteristics and these are affected by morphological changes during the growth cycle and also by culture conditions (Jensen, I933; Cure \& Keddie, 1972). Furthermore, some Corynebacterium species are morphologically similar to Propionibacterium and Brevibacterium while other members of the genus, together with the genera Arthrobacter and Cellulomonas, show a close 
morphological resemblance to representatives of the genera Mycobacterium and Nocardia (Jensen, 1952; Skerman, 1967; Bowie, Grigor, Dunckley, Loutit \& Loutit 1972).

The taxonomic situation is further complicated by the inclusion of the genera Listeria and Erysipelothrix in the family Corynebacteriaceae (Bergey's Manual of Determinative Bacteriology, 1957). These two genera do not exhibit coryneform morphology and, together with the species Micro. thermosphactum, are physiologically more closely related to the Lactobacillaceae (Davis Fomin, Wilson \& Newton, I969; Stuart \& Pease, I972; CollinsThompson Sørhaug, Witter \& Ordal, 1972; Trivett \& Meyer, I97I; Wilkinson, I973).

There are a number of reviews of the early literature (Clark, 1952; Jensen, I934, I952, I966; Gibson, I953; Veldkamp, I970). In the past ten years there have been an increasing number of studies of the taxonomy of coryneform and possibly related bacteria by numerical taxonomic methods (Da Silva \& Holt, I965; Melville, I965; Chatelain \& Second, I966; Harrington, 1966; Mullakhanbhai \& Bhat, 1967; Splitstoesser, Wexler, White \& Colwell, I 967; Seyfried, I 968; Davis et al. 1969; Davis \& Newton, I 969; Masuo \& Nakagawa, I969; Skyring \& Quadling, 1970; Bousfield, 1972; Vanderzant, Judkins, Nickelson \& Fitshugh, 1972; Goodfellow, Fleming \& Sackin, 1972) and by other techniques (Keddie, Leask \& Grainger, 1966; Robinson, I966a, b, $c$; Abe, Takayama \& Kinoshita, 1967; Komagata, Yamada \& Ogawa, I969; Yamada \& Komagata, I968, I970a, b, I972a, b; Modarska, Modarski \& Goodfellow, 1972). However, with a few exceptions (Stuart \& Pease, 1972; Bousfield, I 972; Yamada \& Komagata I970a, b, I972a, b) all have been concerned with only part of the coryneform area as circumscribed by Jensen (1952, I966).

This study reports an attempt to establish the degree of similarity between the genera Nocardia, Agromyces, Mycobacterium, Kurthia, Brevibacterium, Corynebacterium, Arthrobacter, Cellulomonas, Microbacterium, Listeria, Erysipelothrix, Propionibacterium, Lactobacillus and Streptococcus by a numerical taxonomic study of a number of strains from these genera together with some unclassified bacteria. It was also hoped to clarify the validity of some or all of these genera, leading to a more convincing identification scheme for the coryneform bacteria.

\section{METHODS}

Strains. These are listed in Table I. A few were fresh isolates, but the majority were received from other workers and from culture collections. Type strains were included wherever possible. Each strain was given a study reference number but the original strain designation is given in column 3 of Table I. Several strains which showed colonial variation during preliminary culture were separated into discrete cultures which retained their characteristic morphology on further subculture over a period of years. Mucoid variants of NCIB8 147 and GI 257 were included in the study and are labelled NCIB8I 47 (m) and GI 257 (m). Some strains of Listeria were obtained from different sources and it was later realized that they were in fact the same strain. They were retained in the study because they had different histories and it was of interest to see what effect, if any, this had on their eventual clustering.

The strains were lyophilized and working cultures maintained by weekly subculture on the soil extract medium described below.

Basal medium. The selection of one basal medium which allowed growth of all the bacteria in the study posed a problem. At one extreme were Arthrobacter spp., some of which are inhibited by concentrations of peptone used in routine media and some of which also require 'terregens' factor for growth (Lockhead \& Burton, I956); at the other extreme were nutritionally demanding bacteria, e.g. streptococci, lactobacilli and some animal corynebacteria. Several media were tested. The best medium for this study was a modification of the medium 
Table I. Strains used in the study

Study reference number

Species

Strain

$\mathrm{C} 124 \quad$ Achromobacter liquefaciens

designation

Source

$\begin{array}{ll}\mathrm{C} 265 & \text { Agromyces ramosus } \\ \mathrm{C} 80 & \text { Arthrobacter atrocyaneus }\end{array}$

ATCC1 5716

C76 Arth. aurescens

C79 Arth. citreus

CI22 Arth. citreus

C86 Arth. crystallopoietes

C8I Arth. duodecadis

C83 Arth. flavescens

C7 I Arth. globiformis

Cr23 Arth. globiformis

$\mathrm{C} 84 \quad$ Arth nicotianae

C74 Arth. oxydans

C75 Arth. oxydans

$\mathrm{C}_{72}$ Arth. pascens

C85 Arth. ramosus

C73 Arth. simplex

C120 Arth. simplex

C82 Arth.terregens

C78 Arth.tumescens

C77 Arth. ureafaciens

C12 I Arth. ureafaciens

C87 Arth. variabilis

Cr30 Arthrobacter sp.

Ci29 Arthrobacter sp.

Ci33 Arthrobacter sp.

Ci36 Arthrobacter sp.

Ci3I Arthrobacter sp.

ATCC25173

NCIB9220

NCIB89I 2

NCIB89I 5

M8909

NCIB9499

$\mathrm{NClB9222}$

NCIB922 I

$\mathrm{NClB} 8602$

M89 I I

NCIB9458

NCIB9333

$\mathrm{NCIB9334}$

NCIB89IO

NCIB9066

NClB8929

M89 I 3

NCIB8909

NClB8914

NCIB781 I

M8916

NCIB9455

$\mathrm{Cr} 38$

Ci26

Cr 34

Ci 35

Ci 37

Ci 28

CI 27

Cr 32

Ci 40

Ci4 I

CI43

Ci 59

Ci6o

Ci6I

Ci62

Cr63

Ci64

Cr65

Ci66

CI 67

Ci 68

Ci 69

Ci 70

CI7I

CI72

C236

C246

C250

C207

C208

Arthrobacter sp.

Arthrobacter sp.

I

4
8

II

Arthrobacter sp.

326

328

Arthrobacter sp.

Arthrobacter sp.

Arthrobacter sp.

365

Arthrobacter sp.

Arthrobacter sp.

CI 40

Arthrobacter sp.

CI 4 I

Arthrobacter sp.

CI43

Arthrobacter sp.

G93

Arthrobacter sp.

GIO9

Arthrobacter sp.

GI43

Arthrobacter sp.

GI 54

Arthrobacter sp.

GI 87

Arthrobacter sp.

$\mathrm{H} 72$

Arthrobacter sp.

$\mathrm{HI} 23$

Arthrobacter sp.

J30

Arthrobacter sp.

J39

Arthrobacter sp.

J4I

Arthrobacter sp.

Arthrobacter sp.

J52

J62

Arthrobacter sp.

J93

TG I

Arthrobacter sp.

A I $37 / 68$

Arthrobacter sp.

Brzin

Bacterium eurydice

C207

Ba. eurydice

C208

J. G. Morris

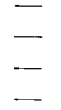

J. G. Morris

J. G. Morris

J. G. Morris

E. G. Mulder

E. G. Mulder

E. G. Mulder

E. G. Mulder

E. G. Mulder

E. G. Mulder

E. G. Mulder

E. G. Mulder

E. G. Mulder

E. G. Mulder

E. G. Mulder

E. G. Mulder

E. G. Mulder

M. Goodfellow

M. Goodfellow

M. Goodfellow

R. M. Keddie

R. M. Keddie

R. M. Keddie

R. M. Keddie

R. M. Keddie

R. M. Keddie

R. M. Keddie

R. M. Keddie

R. M. Keddie

R. M. Keddie

R. M. Keddie

R. M. Keddie

R. M. Keddie

R. M. Keddie

J. G. Morris

L. R. Hill

B. Brzin

L. Bailey

L. Bailey 
Table I (cont.)

Study reference number

$\begin{array}{ll}\text { C1I } & \text { Ba. eurydice } \\ \text { C26 } & \text { Brevibacterium acetylicum } \\ \text { C93 } & \text { Br. ammoniogenes } \\ \text { C94 } & \text { Br. divaricatum } \\ \text { C25 } & \text { Br. imperiale } \\ \text { C24 } & \text { Br. incertum } \\ \text { C23 } & \text { Br. leucinophagum } \\ \text { C21 } & \text { Br. linens } \\ \text { C92 } & \text { Br. linens } \\ \text { C22 } & \text { Br. stationis } \\ \text { C95 } & \text { Cellulomonas biazotea } \\ \text { C100 } & \text { Cel. bibula } \\ \text { C96 } & \text { Cel. cellasea } \\ \text { C97 } & \text { Cel. fimi } \\ \text { C99 } & \text { Cel. flavigena } \\ \text { C98 } & \text { Cel. gelida } \\ \text { C101 } & \text { Cel. rossica } \\ \text { C102 } & \text { Cel. subalbus } \\ \text { C27 } & \text { Cel. uda }\end{array}$

C67 Corynebacterium aquaticum

C35 Cor. betae

CI 3 Cor. bovis

C4 I Cor. diphtheriae

C223 Cor diphtheriae

$\mathrm{C} 224$ Cor.diphtheriae

C225 Cor.diphtheriae

$\mathrm{C} 48$ Cor.equi

C17 Cor.fascians

C36 Cor.fascians

C37 Cor. flaccumfasciens

C45 Cor.haemolyticum

CIO Cor. hofmanii

Ci 8 Cor. ilicis

$\mathrm{C}_{3} 8$

$\mathrm{C} 69$

C69

C34

C65

C66

$\mathrm{C} 47$

Ci 5

$\mathrm{C}_{42}$

$\mathrm{CI} 4$

$\mathrm{C}_{40} \mathrm{O}$

$\mathrm{C} 44$

C249

C39

$\mathrm{C} 46$

C70

Ci 6

C64

$\mathrm{C}_{43}$

$\mathrm{C} 63$

C239

C206

Ci 80

$\mathrm{C}_{176}$

CI8I
Cor. insidiosum

Cor. manihot

Cor. mediolanum

Cor. michiganense

Cor. minutissimum

Cor. minutissimum

Cor. murium

Cor. nephridii

Cor. ovis

Cor. paurometabolum

Cor. poinsettiae

Cor. pyogenes

Cor. pyogenes

Cor. rathayi

Cor. renale

Cor. rubrum

Cor, vesiculare

Cor. viscosum

Cor. xerosis

Corynebacterium sp.

Corynebacterium sp.

Corynebacterium sp.

Corynebacterium sp.

Corynebacterium sp.

Corynebacterium sp.
Strain

designation

Source

CI I

ATCC953

NCIB8143

NCIB9379

ATCC 8365

ATCC 8363

ATCC 13809

ATCC9174

NCIB8546

ATCC 14403

NCIB 8077

$\mathrm{NCIB} 8 \mathrm{I} 42$

$\mathrm{NCIB} 8078$

$\mathrm{NCIB} 8980$

$\mathrm{NCIB} 8073$

$\mathrm{NCIB} 8076$

$\mathrm{NCIB} 8074$

NCIB8075

ATCC49 I

NCIB9460

NCPPB 363

ATCC 77 15

NCTC 3984

NCTC 3985

NCTC3989

Bergan 8

NCTCI 62 I

ATCC 12974

NCPPB I 488

NCPPB 559

NCTC 8452

S45

ATCCI 4264

NCPPB8 3

NCIB9097

NCIB7206

NCPPB I 468

NCTC I 0284

NCTCI 0288

NCTC949

ATCC I I 425

NCTC 3450

ATCC 8368

NCPPB 844

NCTC5224

C249

NCPPB 797

NCTC 7448

NCIB9433

ATCC I I 426

NCTC2416

NCTC9755

NCTC7510

UI 35

C206

3-8

6-10

7-I I
L. Bailey

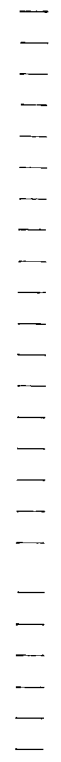

P. H. A. Sneath
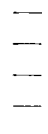

C. S. Cummins
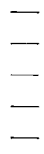

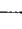

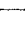
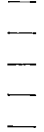

N. S. Mair

H. R. Carne

C. Ratledge

H. E. Schefferle

H. E. Schefferle

H. E. Schefferle 
Table I (cont.)

Study reference number

Species

Ci77 Corynebacterium $\mathrm{sp}$

Ci79 Corynebacterium sp.

Ci78 Corynebacterium sp.

Ci9I Corynebacterium $\mathrm{sp}$.

Cr89 Corynebacterium sp.

Cr9o Corynebacterium $\mathrm{sp}$.

Cr87 Corynebacterium $\mathrm{sp.}$

CI 88 Corynebacterium sp.

Ci 86 Corynebacterium $\mathrm{sp.}$

Ci85 Corynebacterium sp.

$\mathrm{Cr} 82$ Corynebacterium $\mathrm{sp}$.

$\mathrm{Cr} 84$ Corynebacterium sp.

$\mathrm{Cr} 83$ Corynebacterium sp.

C243 Corynebacterium sp.

C245 Corynebacterium sp.

$\mathrm{C} 244 \quad$ Corynebacterium $\mathrm{sp}$.

Ci 8 Diphtheroid Q

C50 Erysipelothrix rhusiopathiae

$\mathrm{C220}$ E. rhusiopathiae

C221 E. rhusiopathiae

C2I9 E. rhusiopathiae

C218 E. rhusiopathiae

C2I 7 E. rhusiopathiae

Cro7m Jensenia canicruria

Cro7c J. canicruria

C5I Kurthia zopfii

C9I K. zopfii

C5 $\quad$ K. zopfii

C6 K. zopfii

C7 K. zopfii

C205 Kurthia sp.

Cr25 Kurthia sp.

C232 Lactobacillus casei var rhamnosus

C233 Lact. plantarum

C210 Atypical Lactobacillus

C209 Atypical Lactobacillus

C2I I Atypical Lactobacillus

$\mathrm{C} 2 \mathrm{I} 2$ Listeria denitrificans

$\mathrm{C}_{2} \mathrm{I}$ List. grayi

C23 I List. monocytogenes

C226 List.monocytogenes

$\mathrm{C2O} 3 \quad$ List. monocytogenes

C227 List.monocytogenes

$\mathrm{C2O} 2$ List. monocytogenes

$\mathrm{C}_{22} 2$ List. monocytogenes

C229 List. monocytogenes

C200 List. monocytogenes

$\mathrm{C}_{52} \quad$ List. monocytogenes

C230 List. monocytogenes

C2OI List. monocytogenes

Ci98 List. monocytogenes

C199 List. monocytogenes

C197 List. monocytogenes

C2 6 List. monocytogenes

C196 List. monocytogenes

$\mathrm{C}_{235}$ List. monocytogenes

$\mathrm{C} 242$ List. monocytogenes

$\mathrm{C} 248$
Strain

designation

8-7

IO-2 I

I I - IO

3A 4302

3A 4429

3A 4555

3A 4669

3A 4675

3A 47 I 5

3A 4794

4 C 1528

4D 9312

3w 8957

NCIB8I 79

NCIB8I 81

NCIB8 180

NCTC 7420

NCTC8I 63

Sneath 19

Sneath 45

Sneath 49

Sneath 53

Sneath I 5

$\mathrm{NClB} 8147 \mathrm{~m}$

NCIB8I 47

NCTC4O4

$\mathrm{NCIB} 8603$

$\mathrm{K} 2$

s8

s9

8

F64/100

$\mathrm{NCDO} 243$

NCDO 1752

LTRS MTI

LTRS MT7

LTRS MT36

L26

Seeliger L332/64

NCTC 4883

NCTC4885

NCTC4885 (Mair)

NCTC5IO5

NCTC5IO5 (Mair)

NCTC52 14

NCTC 5343

NCTC5348

NCTC7973a

NCTC7973

NCTCI0357

Mair CI 98

Mair 2643 I

Mair 2825 I

Mair C2 16

Mair Cig6

MRC C235

Brzin

Mair C248
Source

H. E. Schefferle

H. E. Schefferle

H. E. Schefferle

C. Shaw

C. Shaw

C. Shaw

C. Shaw

C. Shaw

C. Shaw

C. Shaw

C. Shaw

C. Shaw

C. Shaw

P. H. A. Sneath

P. H. A. Sneath

P. H. A. Sneath

P. H. A. Sneath

P. H. A. Sneath

R. M. Keddie

R. M. Keddie

R. M. Keddie

G. A. Gardner

E. M. Barnes

M. E. Sharpe

M. E. Sharpe

M. E. Sharpe

Pasteur Institute, Paris

H. L. Seeliger

N. S. Mair

N. S. Mair

N. S. Mair

N. S. Mair

N. S. Mair

N. S. Mair

N. S. Mair

B. Brzin

N. S. Mair 
Table I (cont.)

Study reference number

$\begin{array}{ll}\mathrm{C} 213 & \text { List. monocytogenes } \\ \mathrm{C} 90 & \text { Microbacterium flavum } \\ \mathrm{C} 88 & \text { Micro. lacticum } \\ \mathrm{C} 89 & \text { Micro. lacticum } \\ \mathrm{C} 20 & \text { Micro. thermosphactum } \\ \mathrm{C} 2 & \text { Micro. thermosphactum } \\ \mathrm{C} 3 & \text { Micro. thermosphactum } \\ \mathrm{C} 4 & \text { Micro. thermosphactum } \\ \mathrm{C} 62 & \text { Micrococcus luteus } \\ \mathrm{C} 29 & \text { Mycobacterium fortuitum } \\ \mathrm{C} 57 & \text { Myco. phlei } \\ \mathrm{C} 58 & \text { Myco. smegmatis } \\ \mathrm{C} 173 & \text { Myco. rhodochrous } \\ \mathrm{C} 174 & \text { Myco. rhodochrous } \\ \mathrm{C} 12 & \text { Myco. rhodochrous }\end{array}$

Ci53 Myco. rhodochrous

C157 Myco. rhodochrous

Ci56 Myco. rhodochrous

Ci55 Myco. rhodochrous

CI44 Myco, rhodochrous

Ci48 Myco. rhodochrous

Ci45 Myco. rhodochrous

C147m Myco, rhodochrous

Ci47c Myco.rhodochrous

Ci46 Myco. rhodochrous

Ci5I Myco. rhodochrous

Ci54 Myco, rhodochrous

Ci58 Myco. rhodochrous

Ci52 Myco.rhodochrous

Ci49 Nocardia brasiliensis

Ci I I N. calcarea

C55 N. caviae

Ci Io N. cellulans

$\mathrm{C} 109$ N. coeliaca

C53 N. farcinica

CiI 2 N. hydrocarboxydans

C54 N. madurae

C108 N. opaca

Ci5o N.pelletieri

Ci 3 N. petroleophila

Ci14 N.rugosa

C56 N. salivae

Ci 55 N. saturnea

Ci94 N. turbata

Ci93 N.turbata

Ci92 N. turbata

$\mathrm{C2} 8$ N. vaccinii

CI42 Nocardia sp.

CrO4 Propionibacterium freundenreichii

C116 P.jensenii

Cio6 P.pentosaceum

C105 P.petersonii

Cio3 P. shermanii

CI17 Streptococcus faecalis

$\mathrm{C}_{32} \quad$ Strep. faecalis

C33 Strep. faecalis

$\mathrm{C} 9 \quad$ Strep. pyogenes

C6I Streptococcus $\mathrm{sp}$. (serological group Q)

Strain

designation

Source

Potel $\mathrm{L} 88 / 7$

NCIB8707

NCIB8540

NCIB854I

ATCCI 1509

CR I2A

30

$30 \mathrm{~A}$

NCTC 85 I 2

ATCC684I

NCTC8 I 5 I

NCTC8I 59

NCTC8139

NCTCIO2IO

ATCCI 3808

G2 I

G4I 7

G463

G768

G8I7

GI 240

GI 256

GI 257M

GI 257

GI 293S

G I 293R

G3048

G7698

ATCC 12975

G744

NCIB8863

NCTCI 934

NCIB8868

NCIB8939

NCTC 4524

NCIB9436

NCTC 5654

NCIB9409

G5I 3

NCIB9438

NCIB8926

NCTC 10207

NCIB9437

CI94 (strain A)

CI93 (strain B)

C 192 (strain C)

ATCCI IO92

CI 42

NCIB 5959

NCIB5960

NCIB8070

NCIB5962

NCIB8099

NCIB6782

T9I

P31 8

s6

NCTC6r98
H. L. Seeliger

A. G. Kitchell

A. G. Kitchell

A. G. Kitchell

R. E. Gordon

R. E. Gordon

R. E. Gordon

R. E. Gordon

R. E. Gordon

R. E. Gordon

R. E. Gordon

R. E. Gordon

R. E. Gordon

R. E. Gordon

R. E. Gordon

R. E. Gordon

R. E. Gordon

R. E. Gordon

R. E. Gordon
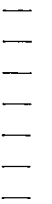

R. E. Gordon

D. M. Webley

D. M. Webley

D. M. Webley

M. Goodfellow
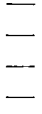

R. H. Deibel

R. H. Deibel

C. S. Cummins 
of Topping (I937). This contained: neopeptone (Difco), $2.5 \mathrm{~g}$; yeast extract (Difco), $2.5 \mathrm{~g}$; glucose, 2.5 g; Tween 80 (Koch-Light), I g; agar (Davies), I $5 \mathrm{~g}$; soil extract, $250 \mathrm{ml}$; and distilled water to a final volume of $\mathrm{I} 1$, at $\mathrm{pH} 6.8$. The soil extract was prepared by suspending $500 \mathrm{~g}$ air-dried garden soil in I 1 tap water and autoclaving at $120^{\circ} \mathrm{C}$ for $15 \mathrm{~min}$. After sedimentation of the larger particles, the hot supernatant was decanted and clarified by filtration through paper pulp in a Buchner funnel. This procedure produced a clear soil extract which was used in the medium described above. The medium minus agar was also used as a broth. These media, subsequently referred to as SEM agar and SEM broth, were used as the basal medium in most of the tests. Different media minus soil extract were used with certain strains to check the effect of soil extract on the tests, but in no case were the tests greatly affected. All tests were incubated at $30^{\circ} \mathrm{C}$ unless otherwise stated.

Colonial and cell morphology. The bacteria were grown on SEM agar and examined under a low-power microscope for colonial morphology after I, 2, 4 and 7 days at $\times 100$ and $\times 400$ magnifications. Gram stains were performed at the same times and examined at $\times 1000$ magnification. Spore stains were done on 7 day cultures. Acid fastness was investigated using 5 day cultures grown on SEM agar supplemented with glycerol $(7 \%$, w/v).

Pigment production was noted in colonies examined for colonial morphology. After 7 days the cultures were removed from the incubator and left in light at room temperature for I4 days.

Growth characteristics in liquid medium were examined in SEM broth at I, 2, 4 and 7 days.

Ability to grow on and/or haemolyse blood was tested by culturing the bacteria on blood agar base (Oxoid) plus $7 \%(\mathrm{v} / \mathrm{v})$ sterile horse blood. Petri dishes were examined daily for 5 days for growth and type of haemolysis.

Henry technique (irridescence). Twenty-four h Petri dish cultures of bacteria on tryptose agar (Difco) were examined microscopically with obliquely transmitted white light following the technique of Henry (1933) as described by Wood (1969). Listeria spp. appear as small, low convex colonies with a bright blue-green irridescence.

Growth at different temperatures. Bacteria were incubated in tubes of SEM broth at 4 , Io, $25,30,37,45$ and $50{ }^{\circ} \mathrm{C}$ in water baths maintained at the given temperature $\pm \mathrm{I}{ }^{\circ} \mathrm{C}$. Turbidity was scored as slight, moderate or dense for up to 7 days, or up to 2 I days for growth at 4 and $10^{\circ} \mathrm{C}$.

Survival at $60{ }^{\circ} \mathrm{C}$ for $30 \mathrm{~min}$. Tubes of SEM broth (preheated to $60^{\circ} \mathrm{C}$ ) were inoculated with 2 loopfuls $\left(4.0 \mathrm{~mm}\right.$ diam) of $\mathrm{I} 8 \mathrm{~h}$ cultures, held at $60^{\circ} \mathrm{C}$ for $30 \mathrm{~min}$, cooled immediately, incubated at $30{ }^{\circ} \mathrm{C}$ and examined for growth at intervals for 7 days.

Motility. SEM medium (agar reduced to a concentration of $0.25 \%$ ) was dispensed into wide-necked I oz Universal bottles each containing a Craigie tube. The inner tube was inoculated with the bacterium under study, then incubated at room temperature. The medium surrounding the tube was examined for surface growth and microcolonies in the outer region at frequent intervals for up to 6 weeks. Motile cultures were stained for flagella by the method of Rhodes (I958).

Catalase, benzidine, oxidase. Bacterial growth on SEM agar Petri dishes was used for these tests. Any strain giving a negative result after $24 \mathrm{~h}$ growth was retested at $48 \mathrm{~h}$ and in some cases at 3 to 5 days. $\mathrm{H}_{2} \mathrm{O}_{2}(20 \mathrm{vol}$.) was used to test for catalase; the benzidine test was carried out by the method of Deibel \& Evans (1960); oxidase was tested for by the method of Klinge ( 1960 ), strong oxidase-positive reactions being recorded after io $s$ and weak ones after $30 \mathrm{~s}$ to I min.

Ammonia from peptone. Small portions of broth were removed from SEM broth after 
7 and 2 I days, placed on a white tile, and 3 drops of Nessler's reagent (BDH) added. A yellow or orange coloration was scored as positive.

Sensitivity to antibiotics. SEM agar and blood agar base (Oxoid) were used. The Petri dishes were lawned with $0 . \mathrm{I} \mathrm{ml}$ of $48 \mathrm{~h}$ broth cultures by means of a sterile glass spreader. Antibiotics in the form of 'Sentest' discs (Evans Medical Ltd, Liverpool) were then dropped on to the dishes ( 4 per dish). The test dishes were observed after $24 \mathrm{~h}$ and $48 \mathrm{~h}$ incubation and again at 3 to 5 days in the case of the slower-growing bacteria. Zones of total and partial inhibition and also the growth of mutant colonies were recorded.

Cellulose hydrolysis. Cellulolytic activity was investigated by inoculating strains into tubes of SEM broth containing strips of Whatman No. I filter paper, half the length of which was above the level of the liquid. The tubes were observed at frequent intervals for 9 weeks. A positive result was recorded if the filter papel disintegrated completely at the liquid/air interface.

Gelatin hydrolysis. SEM broth plus $15 \%(\mathrm{w} / \mathrm{v})$ gelatin (Oxoid) dispensed in $10 \mathrm{ml}$ quantities was inoculated by straight wire. After incubation at $30^{\circ} \mathrm{C}$ the tests were observed at frequent intervals for 6 weeks. Before reading, the tubes were refrigerated at $4{ }^{\circ} \mathrm{C}$ for I $\mathrm{h}$ to solidify the unaffected gelatin.

Chitin hydrolysis. Chitin (BDH) was ground in a ball mill to produce a fine powder, then incorporated into SEM agar to give a concentration of $0.5 \%(\mathrm{w} / \mathrm{v})$. After sterilization at I $20{ }^{\circ} \mathrm{C}$ for $15 \mathrm{~min}$, the chitin was evenly dispersed through the molten agar before dispensing into Petri dishes. Cultures were streaked in one line (two strains/dish) of growth. The dishes were incubated and observed for areas of clearing at intervals for nine weeks.

Casein hydrolysis. An equal volume of $10 \%(\mathrm{w} / \mathrm{v})$ skim milk (Oxoid) in distilled water was added to SEM agar $(2 \times$ normal agar concentration). Some bacteria were also tested on SEM agar minus glucose and on blood agar base plus skim milk. The Petri dishes were prepared, inoculated and read as for chitin hydrolysis for $2 \mathrm{I}$ days. There was no difference in the results with those bacteria tested on the three media.

Egg yolk reaction. Sterilized SEM medium was allowed to cool to approximately $50{ }^{\circ} \mathrm{C}$. Egg yolk emulsion (Oxoid) previously heated to $50{ }^{\circ} \mathrm{C}$ was then added to give a final concentration of $10 \%(\mathrm{v} / \mathrm{v})$. The medium was mixed, dispensed into Petri dishes and inoculated as described for chitin hydrolysis. Dishes were examined for the appearance of opalescence around the colonies for $2 \mathrm{I}$ days.

Deoxyribonuclease. Bacteria were grown on SEM agar plus $2 \%(\mathrm{w} / \mathrm{v})$ deoxyribonucleic acid and $0.08 \%(\mathrm{w} / \mathrm{v}) \mathrm{CaCl}_{2}$, and most were also tested on the medium of Di Salvo (I958). The Petri dishes were inoculated as described under chitin hydrolysis. After 5 days (Io days for slow-growing bacteria) the dishes were flooded with $\mathrm{I} \mathrm{N}-\mathrm{HCl}$ and inspected for areas of clearing.

Urease. The medium consisted of $50 \mathrm{ml} 20 \%(\mathrm{v} / \mathrm{v})$ urea (sterilized by membrane filtration), added to $500 \mathrm{ml}$ of sterilized molten SEM agar minus yeast extract and glucose and with the peptone concentration reduced to $0.01 \%$ but with $0.012 \mathrm{~g}$ of phenol red as indicator; this was dispensed in $10 \mathrm{ml}$ quantities into test tubes and allowed to set as slopes. After inoculation the tubes were inspected daily for 2 I days for development of red colour.

Tween hydrolysis. Tween 20, 40,60 and 80 (Koch-Light), at final concentrations of I \% $(\mathrm{v} / \mathrm{v})$, were added to SEM agar minus Tween 80, plus 0.0I (w/v) $\mathrm{CaCl}_{2}$. After sterilization at $\mathrm{I} 20^{\circ} \mathrm{C}$ for $\mathrm{I} 5 \mathrm{~min}$ the medium was dispensed into Petri dishes and inoculated as described for chitin hydrolysis. Zones of precipitation of the calcium salt and zones of clearing were recorded. In some cases both phenomena occurred together, in others separately. The mechanism of clearing on these media is unknown. 
Aesculin. The medium and method of Sneath (1966) were used, except that the medium was made up in $75 \%$ distilled water and $25 \%$ soil extract. Blackening and loss of purple fluorescence were recorded; the former sometimes occurred without loss of purple fluorescence.

Arginine. (i) SEM broth plus $0.3 \%(\mathrm{w} / \mathrm{v})$ arginine distributed in $5 \mathrm{ml}$ amounts in test tubes was used. After inoculation, drops were aseptically removed for periods up to $2 \mathrm{I}$ days and tested with Nessler's reagent. (ii) Thornley's arginine medium (Thornley, 1960) modified by the inclusion of $25 \%$ soil extract was used.

Xanthine. SEM agar plus $0.5 \%(\mathrm{w} / \mathrm{v})$ xanthine autoclaved at $120^{\circ} \mathrm{C}$ for $15 \mathrm{~min}$ was dispensed into Petri dishes. The dishes were inoculated as described for chitin and examined for areas of clearing for $2 \mathrm{I}$ days.

Tyrosine. SEM agar plus $0.5 \%(\mathrm{w} / \mathrm{v})$ L-tyrosine autoclaved at $120{ }^{\circ} \mathrm{C}$ for $\mathrm{I} 5 \mathrm{~min}$ was dispensed into Petri dishes, care being taken to ensure even distribution of the tyrosine. The dishes were inoculated as described for chitin hydrolysis and inspected for clearing due to decomposition of the tyrosine or production of brown pigment, or both, at intervals up to 2 I days. Some of the bacteria were also tested on blood agar base medium (Oxoid) plus tyrosine. The results were identical on both media.

Nitrate reduction. Bacteria were inoculated into SEM broth plus $0 \cdot \mathrm{I} \%(\mathrm{w} / \mathrm{v}) \mathrm{KNO}_{3}$, dispensed in $10 \mathrm{ml}$ quantities in tubes containing an inverted Durham tube. The tubes were examined at frequent intervals for $2 \mathrm{I}$ days for the presence of gas in the Durham tube. At the same time samples were removed and tested for the presence of nitrite and hydroxylamine by the methods described by Wilson \& Miles (1964). Negative tests were checked at 2I days by the addition of zinc dust to reduce residual nitrate to nitrite.

Hippurate hydrolysis. SEM broth samples containing $\mathrm{I} \%(\mathrm{w} / \mathrm{v})$ sodium hippurate in $10 \mathrm{ml}$ quantities in I oz bottles were inoculated and incubated for 2I days. Each broth was then centrifuged, and two I $\mathrm{ml}$ samples were removed; to one was added $0.5 \mathrm{ml}$ of $12 \%(\mathrm{w} / \mathrm{v})$ ferric chloride and to the other I $\mathrm{ml} 50 \%$ (v/v) sulphuric acid (Davis, I955). Both test methods were used because weak positive reactions are frequently only detected by sulphuric acid.

Methyl red and Voges Proskauer (VP) tests. Two media were used: SEM broth containing $0.5 \%$ (w/v) glucose; Hartley's digest broth (Oxoid) plus $0.5 \%(\mathrm{w} / \mathrm{v}) \mathrm{K}_{2} \mathrm{HPO}_{4}$ and $\mathrm{c} .5 \%$ $(\mathrm{w} / \mathrm{v})$ glucose. Both media were dispensed in $\mathrm{Io} \mathrm{ml}$ quantities. After inoculation the broths were tested at 2, 4 and 7 days as described by Cowan \& Steel (I965), Barritt's method being used for the VP reaction.

Production of acid from carbohydrates. Difficulty was experienced with yeast extract (Difco and Oxoid). Acid was produced by a number of lactic acid bacteria, notably the streptococci and Listeria spp., from the basal medium minus any added carbohydrate.'At first the soil extract was suspect, but then tests indicated it was probably due to the trehalose content of the yeast extract and it was overcome by lowering the concentration of this constituent to $0 \cdot \mathrm{I} \%(\mathrm{~W} / \mathrm{v})$ and always including a sugarless control.

Two basal media were used. (i) Peptone (Difco), I5 g; yeast extract (Difco), I g; Tween 8o, I g; water, I l. (ii) SEM broth minus glucose, and with the yeast extract concentration reduced to $0.1 \%$. In both cases the indicator was $3 \mathrm{ml}$ of $\mathrm{I} \%$ aqueous brom-cresol purple $/ 1$ media. The appropriate carbohydrates were added as filter-sterilized solutions to the sterilized basal media to give a final concentration of I \%.

The tests were also carried out in two ways: in test tubes, and in divided dishes (Sneath \& Stevens, 1967). When tests were performed in divided dishes, $0.5 \%$ agar (standard agar Davies) was added. The tubes were incubated at $30{ }^{\circ} \mathrm{C}$, but the divided dishes were incubated 
at $23{ }^{\circ} \mathrm{C}$ because at $30{ }^{\circ} \mathrm{C}$ some strains formed large quantities of mucoid material which 'crept' over the divisions in the dishes. All tests were read daily for $2 \mathrm{r}$ days.

Oxidative/fermentative utilization of glucose. The method of Hugh \& Leifson (1953) was used, except that the two basal media were those described above. Additionally, one set of tubes was incubated in an anaerobic jar under an atmosphere of hydrogen rather than with the Vaseline seal.

Starch hydrolysis. A $10 \%(\mathrm{w} / \mathrm{v})$ aqueous starch solution was dissolved by heating and added to SEM agar minus glucose to give a final concentration of $0.2 \%(\mathrm{w} / \mathrm{v})$. Petri dishes were inoculated as described for chitin hydrolysis. After 7 to Io days of incubation the dishes were flooded with iodine solution and examined for clearing around and under the growth.

Phosphatase. A I \% (w/v) aqueous solution of phenolphthalein diphosphate (Na salt; $\mathrm{BDH})$ sterilized by filtration was added to molten SEM agar to give a final concentration of $0.001 \%(\mathrm{w} / \mathrm{v})$. The medium was dispensed in Petri dishes and inoculated with bacteria so that discrete colonies were obtained. After 7 days, I ml concentrated ammonia solution was placed in the lid of each inverted dish and allowed to stand for ro min. A positive reaction was indicated by the appearance of a pink coloration around the colonies due to the free phenolphthalein reacting with the ammonia vapour.

Sulphatase. The medium and method used was as described for 'phosphatase', phenolphthalein disulphate (K salt; Koch-Light) being substituted for the diphosphate.

Potassium thiocyanate. SEM agar containing potassium thiocyanate $(2.5,3.75$ and $4.5 \%)$ was dispensed in divided dishes and inoculated as described by Stevens (I969). Growth was compared with that on SEM agar minus potassium thiocyanate for 7 days.

Potassium tellurite. An aqueous solution of potassium tellurite $(10 \%, \mathrm{w} / \mathrm{v})$, sterilized by autoclaving at $120^{\circ} \mathrm{C}$ for $\mathrm{I} 5 \mathrm{~min}$, was added to cooled SEM agar to give final concentrations of $0.0 \mathrm{I}, 0.025$ and $0.05 \%$. The medium was dispensed and inoculated as for potassium thiocyanate. Growth and degree of blackening were compared with that on SEM agar minus potassium tellurite for 7 days.

Thallous acetate. SEM agar containing thallous acetate (0.0I, 0.025 and $0.05 \%$ ) was dispensed, inoculated and growth recorded as for potassium thiocyanate.

Sodium azide. SEM agar containing sodium azide (0.01, 0.02 and $0.05 \%$ ) was dispensed, inoculated and growth recorded as for potassium thiocyanate.

Tetrazolium. An aqueous solution of 2,3,5-triphenyltetrazolium chloride (I0 \%,w/v) was prepared by steaming for $30 \mathrm{~min}$ and added to previously sterilized molten SEM agar to give final concentrations of $0.0 \mathrm{I}$ and $0 . \mathrm{I} \%$ ). The medium was dispensed and inoculated as described for potassium thiocyanate. Growth and reduction of tetrazolium were compared with that on SEM agar for 7 days.

Litmus milk. Litmus milk (Oxoid) was reconstituted as directed by the manufacturers except that $25 \%(\mathrm{v} / \mathrm{v})$ soil extract was used in the distilled water. Cultures were examined daily for reduction before clotting, acid production, alkaline production, clotting and digestion for 2I days.

Utilization of organic acids and glucose as carbon sources. Two methods were used. (i) SEM broth minus glucose, but plus the substrate under test to a concentration of I and $10 \%$ $(\mathrm{w} / \mathrm{v})$, was dispensed into matched test tubes. Growth in SEM broth and SEM broth plus the substrate were compared at I, 2, 4, 7 and I 4 days by absorbance readings in a Bausch \& Lomb spectrophotometer at $550 \mathrm{~nm}$. Positive results were scored only when the growth in the broth plus substrate was at least twice that in the basal broth, as many of the strains showed some growth in SEM broth alone. (ii) Medium and method of Gordon \& Mihm 
(1957); incubation and readings as described above. In some cases the medium was supplemented with soil extract $(25 \%, \mathrm{v} / \mathrm{v})$.

Indole. SEM broth with tryptone substituted for peptone was used. The broths were incubated 14 days and tested by method 2 of Cowan \& Steel (I965).

Hydrogen sulphide production. Slopes of SEM medium supplemented with $0.05 \%(\mathrm{w} / \mathrm{v})$ cysteine hydrochloride (BDH) were inoculated with $24 \mathrm{~h}$ cultures of the test bacteria. Strips of lead acetate paper inserted between the cap and the tube were observed for blackening. The tubes were incubated for 24 days but most positive reactions occurred between 2 and 5 days.

Ability to use $\mathrm{NH}_{4}^{+}$and $\mathrm{NO}_{3}^{-}$as sole nitrogen sources. The method of Owens \& Keddie (1969) was used.

Susceptibility to lysozyme. Bacteria were grown on SEM plates for $48 \mathrm{~h}$ at $30^{\circ} \mathrm{C}$. The growth was removed, resuspended in $\mathrm{I} \cdot 5 \mathrm{ml}$ distilled water, and divided into three parts in $10 \times \mathrm{I} \cdot 2 \mathrm{~cm}$ test tubes. To one set was added $0.5 \mathrm{ml}$ distilled water, to the second $0.5 \mathrm{ml}$ lysozyme solution (I00 $\mu \mathrm{g}$ lysosyme $/ \mathrm{ml}$ ) and to the third $0.5 \mathrm{ml}$ lysozyme plus EDTA solution (100 $\mu \mathrm{g}$ lysozyme and $0.5 \mathrm{mg}$ EDTA/ml) (Metcalf \& Deibel, I969). All the tubes were incubated at $35^{\circ} \mathrm{C}$ for $90 \mathrm{~min}$, and examined for lysis by clearing and for the appearance of a glutinous mass. An equal volume of $\mathrm{NaCl}(3 \%, \mathrm{w} / \mathrm{v})$ was then added to each tube, which was immediately inspected for lysis as described above. Controls were included in all tests and all tests were repeated at least twice.

Coding of characters. Except for the ability to grow on $7 \%(\mathrm{v} / \mathrm{v})$ blood agar, all the results were scored from those media containing soil extract. The Gram reaction was not scored because all strains showed some degree of Gram-positive staining although some strains appeared more Gram-negative. However, this trait was not reproducible, and the mode of regulation of citrate synthase (Jones \& Weitzman, I97I) showed some but not all of these Gram-variable strains to have citrate synthases characteristic of Gram-negative bacteria. These strains are discussed below.

Those characters which existed in one or two mutually exclusive states were scored I (plus) or o (minus). Multistate characters, e.g. degree of acid production, were scored o (minus), I (weak positive) and 2 (strong positive).

Computation. The simple matching coefficient $\left(S_{\mathrm{sx}}\right)$ (Sokal \& Michener, 1958) was computed and clustered by both single linkage (Sneath, 1957) and unweighted pair-group average linkage (Sokal \& Michener, 1958). The I GROUPS (integer groups) program printed character-value statistics on specified groups of bacteria. This program, devised by M. J. Sackin of this Unit, aided the selection of tests important in the characterization of taxonomic groups.

As the maximum number of strains that could be computed at one time was 180 , two runs had to be made. This was done by putting all the facultative anaerobic bacteria plus a selection of other strains into one run, and all the aerobic bacteria plus a selection of facultative anaerobic strains into the second run.

All calculations were carried out on the ICL $4 \mathrm{I} 30$ computer at Leicester University. 


\section{RESULTS}

Clustering

As noted in Methods, it was necessary to split the strains into two groups for computation. Some of the strains were included in both computer runs but the relative numbers from different genera were different in each.

Deviations from the published descriptions were found in a number of the strains studied. Strain LTRS MT7 (atypical lactobacilli, Group I of Thornley \& Sharpe, I959) was strongly catalase-positive and weakly benzidine-positive. Achromobacter liquefaciens (ATCC. 57 I6) was found to be Gram-positive whereas Brevibacterium leucinophagum (ATCCI 3809) was Gram-negative (Jones \& Weitzman, 1974). As noted by Jones, Watkins \& Meyer (1970), Agromyces ramosus differed in several ways from the published description.

Most of the 233 strains grouped in 8 clusters (A, B, C, D, E, F, G, H) at the $75 \%$ similarity level $(\% \mathrm{~S})$. The quantitative taxonomic relationships within and between the clusters are illustrated in the sorted similarity matrices (Figs. I and 2). Dendrograms derived from these matrices are shown in Figs. 3 and 4. Six strains remained outside the main groups formed at $75 \% \mathrm{~S}$ in both computer runs. These were strains received as Ach. liquefaciens (ATCC I 57 r 6 ), Brevibacterium acetylicum (ATCC953), Br. leucinophagum (ATCCI3809), Corynebacterium nephridii (ATCCI I425), Cor. insidiosum ( $\mathrm{NCPPB} 83$ ) and Cellulomonas rossica (NCIB8074).

There was good accord between the clusters obtained in the two computations although some strains moved position. In interpreting the results of the clustering the main information was taken from the computer run containing the greater number of strains in a particular cluster, but information pertinent to the validity and stability of that cluster was also taken from the grouping of the same strains (if they were included) in the other computation. Cluster B (Erysipelothrix and some streptococci) appeared in only one computer run (Figs. I and 3). Cluster H (Nocardia, Mycobacterium) also appeared in one computation only (Figs. 2 and 4 ) but the situation is different because three of the I6 strains were included in the other computation where they joined Cluster F (Figs. I and 3).

Cluster A (Lactobacillus, Listeria, Microbacterium, Streptococcus). Above $80 \% \mathrm{~S}$ this cluster contained four subgroups (Figs. I and 3). A I, with an internal similarity of $90 \% \mathrm{~S}$, contained five strains received as Micro. thermosphactum and one strain received as an atypical Lactobacillus sp. (LTRS MT7). A2 contained Lact. casei, Lact. plantarum and strain LTRS MTI, also received as an atypical Lactobacillus sp. A3 contained 20 strains received as List. monocytogenes, one strain received as List. grayi, one received as Erysipelothrix rhusiopathiae (this was a misnamed strain of List. monocytogenes and serological tests confirmed its position), and an atypical Lactobacillus sp., LTRS MT36. A4 contained three strains received as Strep. faecalis. The position was only slightly different in the other computer run (Figs. 2 and 4 ) where only eight of these strains were included.

Cluster B (Erysipelothrix, Streptococcus). This was a small cluster containing only seven strains (Figs. I and 3). Four of the strains received as E. rhusiopathiae showed a similarity greater than $95 \%$. These joined E. rhusiopathiae (NCTC8I63) and a Streptococcus strain of serological group G at $83 \% \mathrm{~S}$, and all joined one strain of Strep. pyogenes at $80 \% \mathrm{~S}$.

Cluster C (animal corynebacteria, Micro. flavum, some arthrobacters). At about $77 \% \mathrm{~S}$ this cluster contained two subgroups (Figs. I and 3). CI contained I 3 strains: 12 animal Corynebacterium spp. and Micro. flavum. C2 contained a heterogeneous collection of ten strains received as animal Corynebacterium spp., 'Bacterium eurydice', Brevibacterium incertum, Arthrobacter terregens and Agromyces ramosus. In the other computation (Figs. 2 and 4), subgroup C2 did not exist because only Arth. terregens and Agr. ramosus were 
included, but the relationship between the strains was only slightly different. Arthrobacter terregens and Agr. ramosus together with Arthrobacter sp. GI 09 (not included in Figs. I and 3) formed a loose group which joined cluster $\mathrm{C}$ at a level just below $75 \% \mathrm{~S}$. Brevibacterium divaricatum (which in Figs. I and 3 joined Cellulomonas flavigena in cluster D) also joined cluster C.

Cluster D (Cellulomonas and others). This group contained three subgroups (Figs. 2 and 4): Di contained Brevibacterium imperiale, Cellulomonas uda and Microbacterium. lacticum (2 strains); D2 contained Corynebacterium mannihot, Nocardia cellulans and $N$. turbata (three strains); D3 contained Cellulomonas biazotea, Cel. cellasea, Cel. bibula, Cel. gelida, Cel. subalbus, Cel. flavigena and Arthrobacter sp. Gi62. The composition of the groups was very similar in the other computer run (Figs. I and 3) even though Nocardia cellulans, N. turbata and Arthrobacter sp. GI62 were not included in the run. The main difference was the grouping of $\mathrm{Br}$. divaricatum with $\mathrm{Cel}$. flavigena (cf. cluster C, Figs. 2 and 4).

Cluster E (Propionibacterium and others). At $80 \% \mathrm{~S}$ three subgroups formed (Figs. I and 3). EI contained all strains received as Propionibacterium spp. E2 contained Listeria denitrificans and three strains isolated as Corynebacterium spp. from poultry deep litter (Schefferle, 1966). E3 contained one strain received as Corynebacterium sp. and two received as Arthrobacter spp. No Propionibacterium spp. were included in the computer run illustrated in Figs. 2 and 4 but, with the exception of this omission, the composition was similar except for the grouping of Brevibacterium incertum (cluster C, Figs. I and 3) with Corynebacterium sp. (4C I 528).

Cluster F (Arthrobacter, Brevibacterium, Kurthia, Mycobacterium). This was a large cluster which contained I2 groups showing S values of $80 \%$ or greater (Figs. 2 and 4). FI contained seven Kurthia strains. Corynebacterium mediolanum (cf. cluster G, Figs. I and 3) joined this group at $77 \% \mathrm{~S}$. F2, with an overall similarity of $84 \%$, contained I4 strains received as Arth. variabilis, Cor. fascians, Cor. rubrum, Corynebacterium spp. and Mycobacterium rhodochrous. F3, with an overall similarity of $83 \%$, contained 20 strains received as Arthrobacter spp., Cor. paurometabolum, Corynebacterium spp., Jensenia canicruria, Myco. rhodochrous, Nocardia calcarea and N. opaca. Only six strains from subgroup $\mathrm{F}_{2}$ and seven strains from subgroup $\mathrm{F}_{3}$ were included in the computer run illustrated in Figs. I and 3. As can be seen, they merged to form one group (labelled F2) at $83 \% \mathrm{~S}$. Subgroup F4 contained six strains received as Br. linens, Arthrobacter spp. and Corynebacterium spp. (Figs. 2 and 4 ). However, in Figs. I and 3 the group has expanded with a slight drop in overall \% S to include Arth. simplex and Arth. crystallopoietes (these strains grouped with other Arthrobacter spp. in subgroup FI I ; Figs. 2 and 4). F5 (Figs. I and 3) was a small group containing Br. stationis, Br. ammoniogenes, Cor. equi and a Corynebacterium sp. It joined subgroup F2 (Figs. I and 3) at $80 \%$ S. In Figs. 2 and 4 the subgroup is represented by three strains only (Cor. equi was not included in this computer run) and joined subgroup $\mathrm{F}_{4}$ at about $83 \% \mathrm{~S}$.

Subgroup F6 (Figs. 2 and 4) contained I I strains received as Arth. duodecadis, Arthrobacter spp. and Cor. vesiculare. The grouping of the strains in the other computer run (Figs. I and 3) was the same except that two strains, Arthrobacter spp. $\mathrm{H}_{72}$ and J3O, were not included in this computation. Subgroup F7 (Figs. 2 and 4 ) was a small group containing only four strains (Arth. flavescens, Cor. michiganense, Cor. rathayi and Micrococcus luteus NCTC85I2) with an overall similarity of $82 \% \mathrm{~S}$ and joined subgroup F6 at $80 \% \mathrm{~S}$. In Figs. I and 3 the group has expanded to contain Arth. citreus which fell in subgroup Fr 2 in Figs. 2 and 4. Subgroup F8 (Figs. 2 and 4) contained eight strains ( $87 \%$ S) received as Arth. aurescens, 


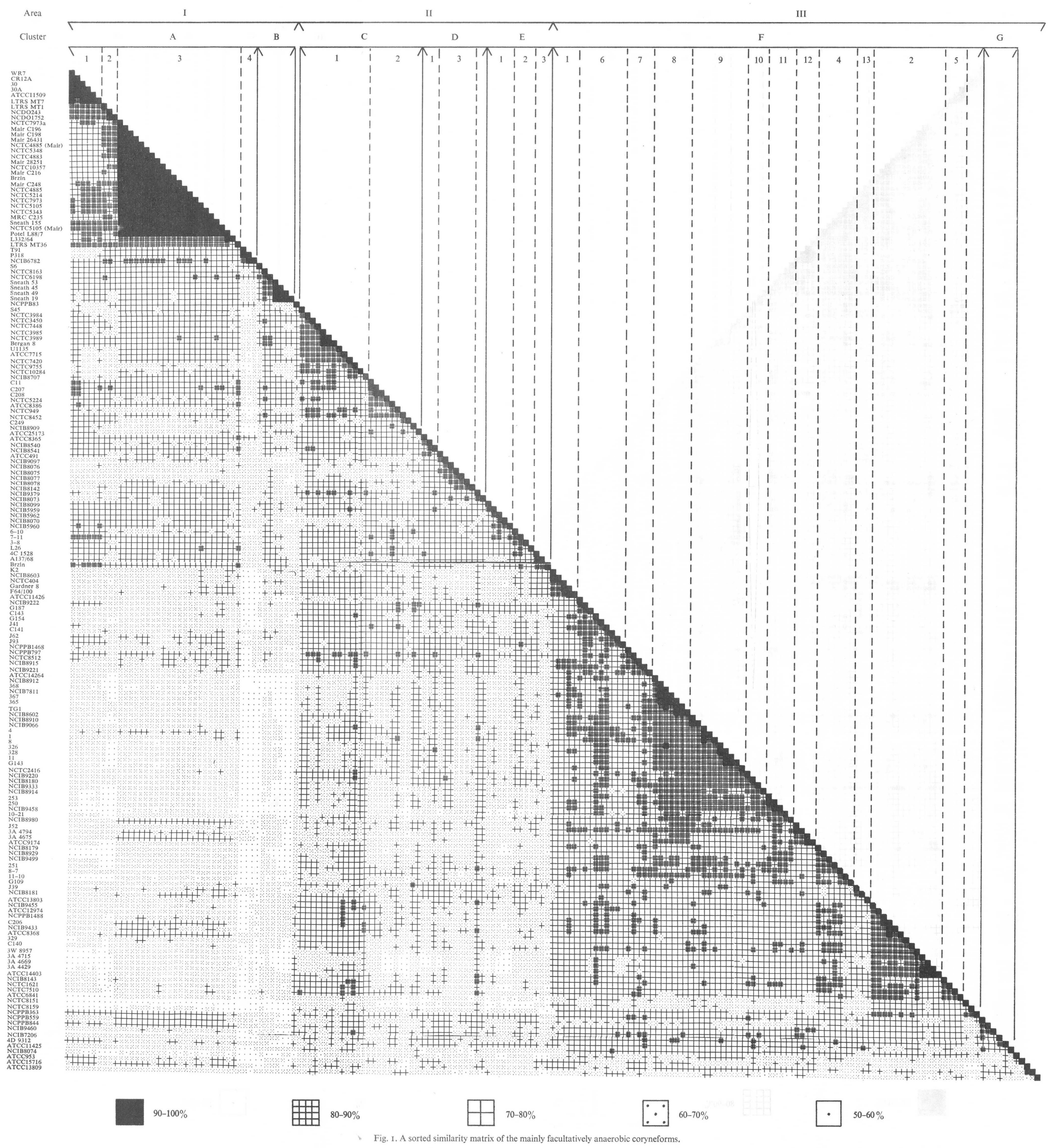




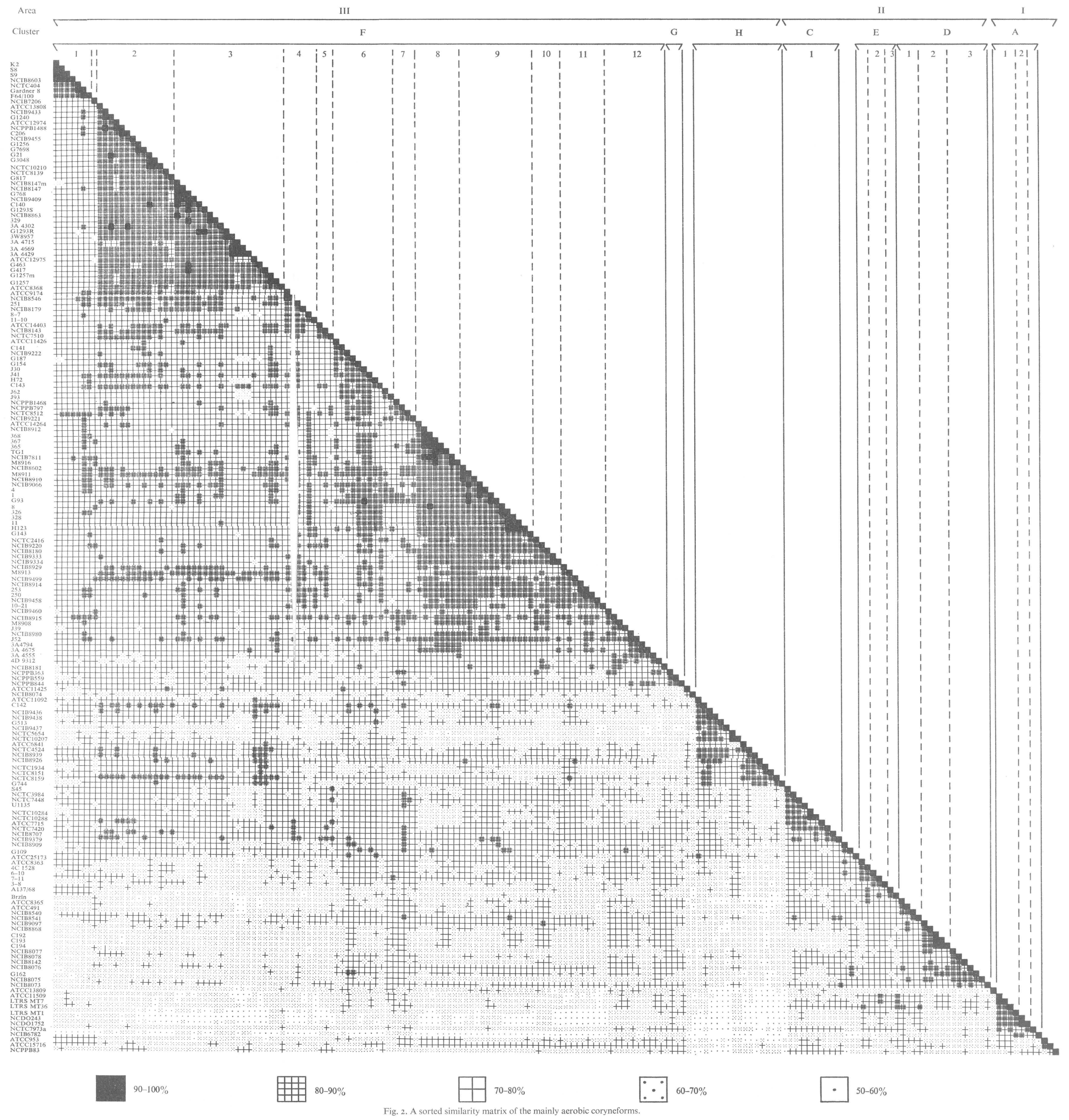


Arth. ureafaciens, Arthrobacter spp. and Cor. ilicis. The composition of the group was exactly the same in Figs. I and 3 except that Arth. ureafaciens M89I 6 was not included.

Subgroup F9 (Figs. 2 and 4) contained 13 strains ( $86 \%$ S) received as Arth. globiformis, Arth. pascens, Arth. ramosus and Arthrobacter spp. The composition of the group is the same in Figs. I and 3 except for the three strains (M89 I I, G93 and HI23) not included. Subgroup Fio (Figs. 2 and 4 ) contained five strains $(85 \%$ S) received as Arth. atrocyaneus, Arth. oxydans, Cor. viscosum and Corynebacterium spp. Arthrobacter oxydans NCIB9334 was not included in the computation illustrated in Figs. I and 3. Subgroup FI I (Figs. 2 and 4) contained eight strains $(83 \% \mathrm{~S})$ received as Arth. crystallopoietes, Arth. nicotianae, Arth. simplex, Arth. tumefaciens and Arthrobacter spp. In Figs. I and 3 this subgroup is reduced to five strains ( $85 \%$ S) because Arth. simplex NCIB8929 and Arth. crystallopoietes clustered in subgroup F4 and Arth. simplex; M8913 was not included. Subgroup FI 2 (Figs. 2 and 4) contained I I strains (approx. $80 \% \mathrm{~S}$ ) received as Arth. citreus, Arthrobacter spp., Cellulomonas fimi, Cor. aquaticum and Corynebacterium spp. In Figs. I and 3 the subgroup is reduced to four strains because four strains were not included, Cor. aquaticum and Corynebacterium sp. 4D 9312 grouped in cluster G, and Corynebacterium sp. NC.IB8I9I clustered with Arthrobacter spp. GI09 and 339 to form a small group labelled FI 3 .

Cluster $G$ (plant pathogenic corynebacteria). This was a small loose group containing six strains, mainly plant pathogenic Corynebacterium spp., with an overall similarity of $76 \%$ (Figs. I and 3). In Figs. 2 and 4, three of the strains have joined subgroups in cluster F.

Cluster $H$ (Figs. 2 and 4). This was a loose group containing 13 named Nocardia spp. and three named Mycobacterium spp. When the Nocardia spp. were not included (Figs. I and 3) the Mycobacterium spp. fell in cluster F, joining subgroup $\mathrm{F}_{5}$ at the $76 \% \mathrm{~S}$ level.

\section{Grouping of clusters}

The eight main clusters grouped into three clear-cut larger areas. Area I containing clusters A and B had an overall similarity of about $74 \%$. Area II containing clusters C, D and E showed an overall similarity of $73 \%$ and joined area I at $7 \mathrm{I} \% \mathrm{~S}$ (Figs. I and 3). These two areas joined area III (overall similarity $70 \% \mathrm{~S}$ ) at approximately $65 \% \mathrm{~S}$ (Figs. 2 and 4 ).

\section{Characterization of groups and clusters}

The ultimate aim of a study of this kind is to devise a system of practical identification. The salient reactions of the strains in the three major areas are listed in Table 2 . The reactions of the strains in the eight clusters in these areas are depicted in Tables 3, 4, 5 and 6 . Table 7 lists the characters which differentiate between Microbacterium thermosphactum, Listeria and Erysipelothrix.

\section{Strain variation and test reproducibility}

Strain variation. As noted in Methods, mucoid variants produced by two cultures, Jensenia canicruria NCIB8147 and Myco. rhodochrous G1257, were included in the study, labelled NCIB8I $47 \mathrm{~m}$ and GI257m respectively. Additionally, duplicates of three strains of Listeria were received from sources other than N.C.T.C. Two were received from Dr N. S. Mair (Public Health Laboratory, Leicester) and are listed as NCTC4885 (Mair) and NCTC5IO5 (Mair). One was an old laboratory strain of NCTC7973 which had been maintained on solid medium for three years before the commencement of the study, and labelled NCTC7973a.

As can be seen from Figs. 2 and 4, there was little difference between the mucoid strains and the parent culture. In addition to the mucoid growth the difference was due to small variations in the degree of antibiotic sensitivity. 
Table 2. Salient characters of the three major areas as percentages of positive reactions

$\begin{array}{cc} & \begin{array}{c}\text { Area II* } \\ \text { Area I* } \\ \text { (Clusters A and B) }\end{array} \\ \text { (Clusters C, D } \\ \text { and E) }\end{array}$

\author{
Area $\mathrm{III} \dagger$ \\ (Clusters F, G \\ and $\mathrm{H}$ )
}

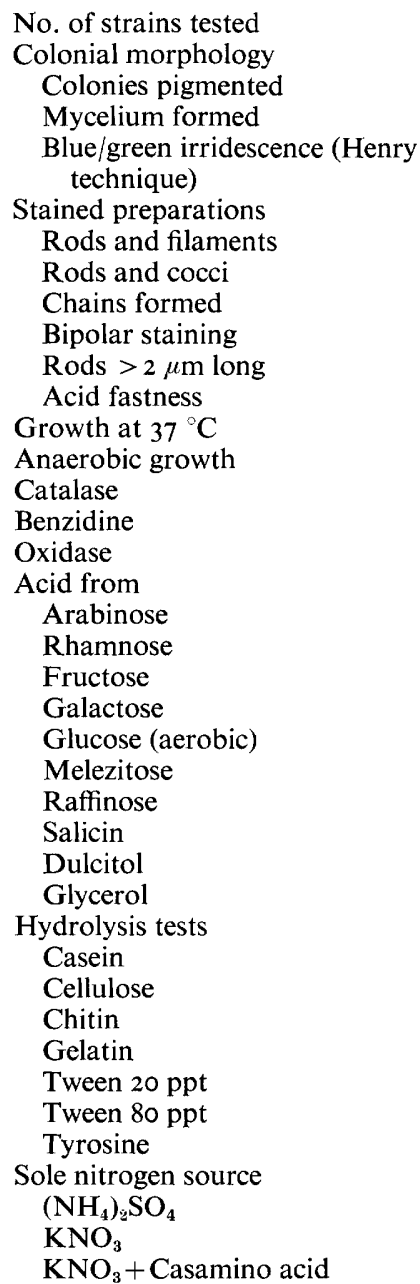

$\begin{array}{rrr}42 & 47 & \text { I } 30 \\ 0 & 40 & 70 \\ 0 & 0 & 22 \\ 45 & 0 & 0\end{array}$

$\begin{array}{rrr}50 & 4 & 5 \\ 0 & 49 & 78 \\ 100 & 34 & 9 \\ 0 & 28 & 1 \\ 0 & 26 & 38 \\ 0 & 17 & 32 \\ 88 & 77 & 28 \\ 100 & 76 & 37 \\ 69 & 83 & 100 \\ 10 & 72 & 100 \\ 0 & 9 & 27\end{array}$

$\begin{array}{lll}40 & 43 & 7\end{array}$

$\begin{array}{lll}74 & 19 & 12\end{array}$

$\begin{array}{lll}100 & 85 & 19\end{array}$

$95 \quad 68 \quad 8$

$100 \quad 100 \quad 22$

$74 \quad 34$

$\begin{array}{rr}38 & 38 \\ 88 & 45\end{array}$

$88 \quad 45 \quad 8$

$8 \mathrm{I} \quad 43 \quad$ I5

$\begin{array}{lll}5 & 34 & 47\end{array}$

$0 \quad 9$

O II 2

$0 \quad-9039$

$\begin{array}{lll}0 & 38 & 87\end{array}$

$\begin{array}{lll}7 & 13 & 76\end{array}$

$\begin{array}{lll}0 & 13 & 65\end{array}$

$\begin{array}{lll}0 & 30 & 82 \\ 0 & 28 & 88\end{array}$

$\begin{array}{rrr}0 & 28 & 88 \\ 38 & 57 & 95\end{array}$

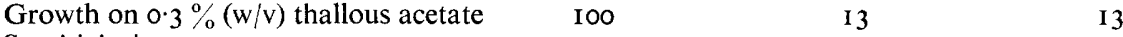

Sensitivity

Sulphonamide $(\mathrm{H})$

Fucidin (L)

Colomycin (L)

Methyl red

Voges Proskauer

Reduction $\mathrm{NO}_{3} \rightarrow \mathrm{NO}_{2}$

Production $\mathrm{H}_{2} \mathrm{~S}$

Urease

$\begin{array}{rr}0 & 38 \\ 45 & 100 \\ 12 & 74 \\ 95 & 77 \\ 83 & 17 \\ 0 & 45 \\ 0 & 19 \\ 0 & 26\end{array}$

* Information derived from material presented in Figs. I and 3.

$\uparrow$ Information derived from material presented in Figs. 2 and 4 but Cellulomonas rossica and Coryne. bacterium nephridii not included.

$+(\mathrm{L})$, low potency; $(\mathrm{H})$, high potency. 


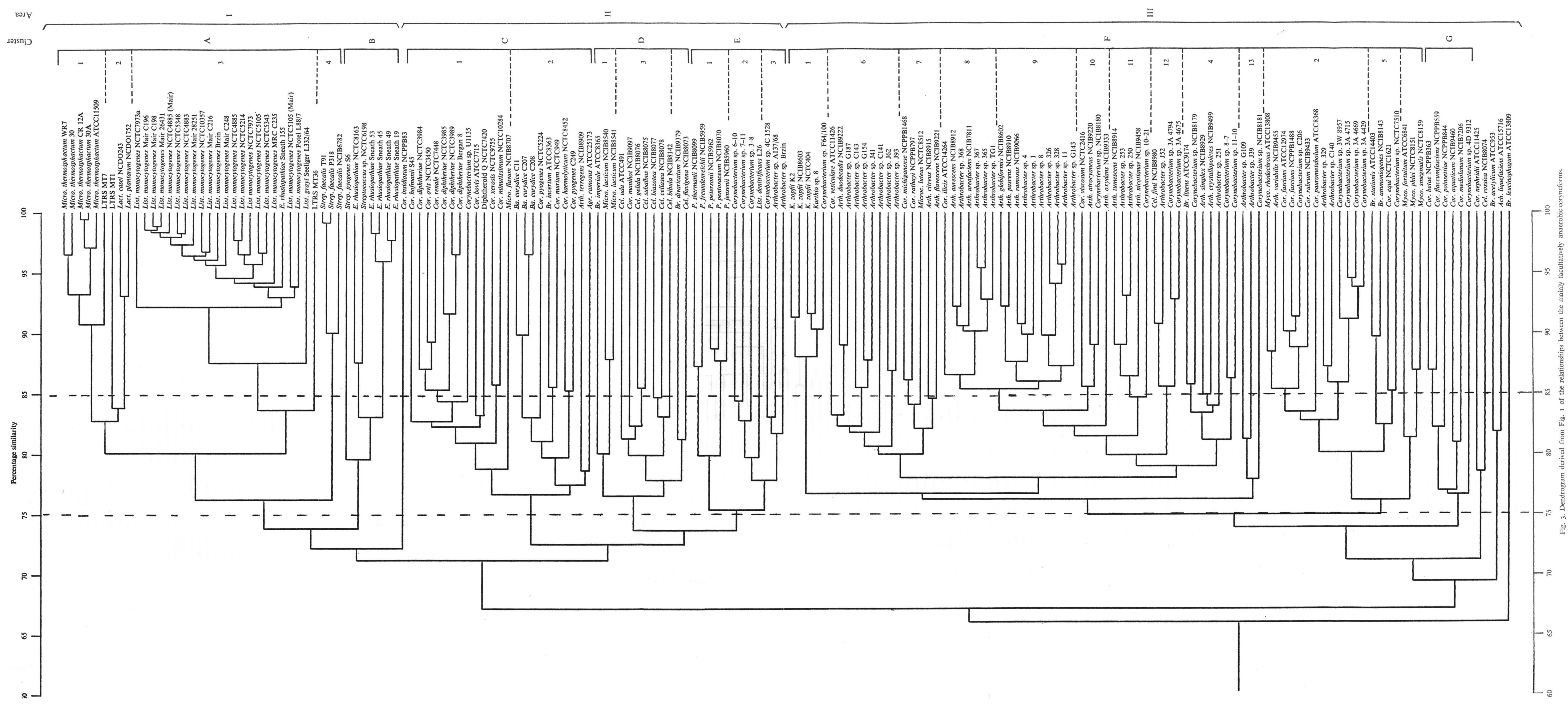




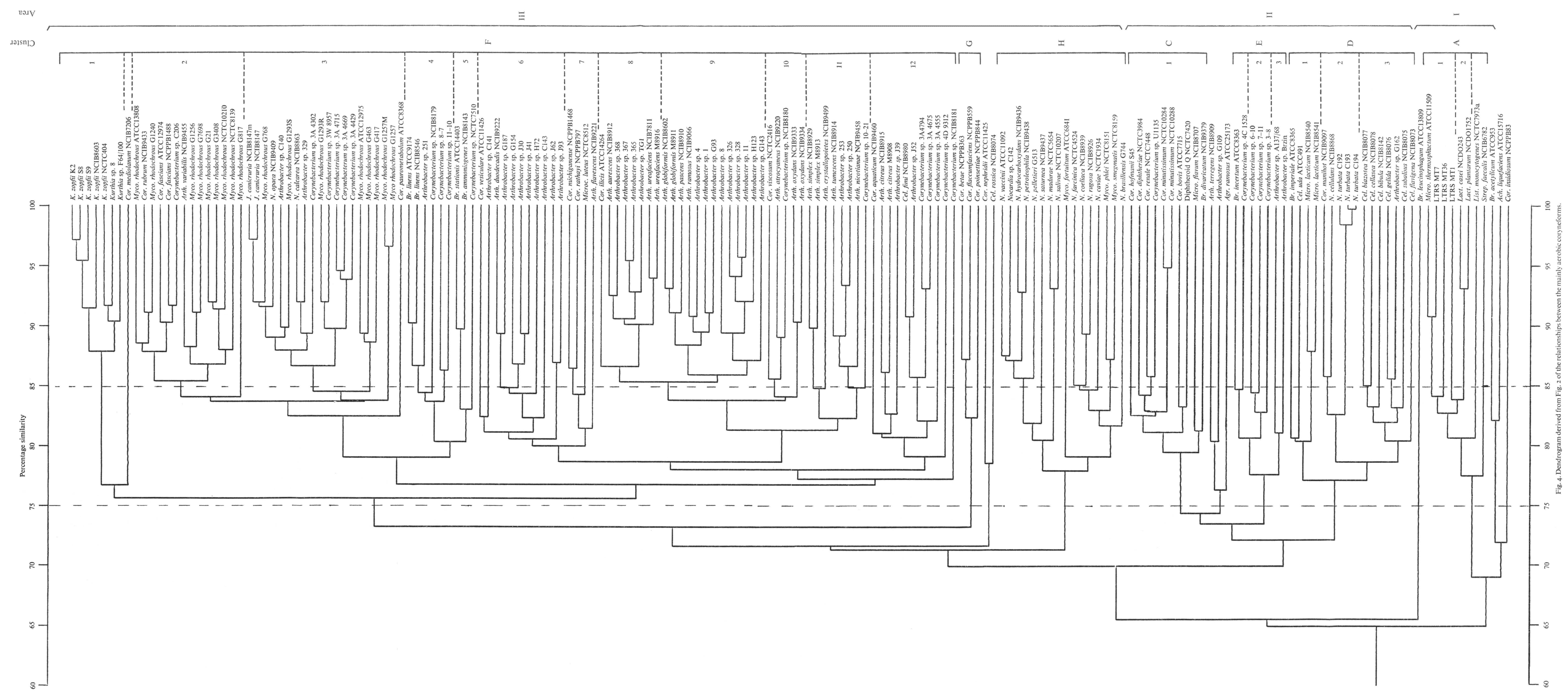


Difference in antibiotic sensitivity was also the main reason for the variation noted between the three pairs of Listeria strains (Figs. I and 3). The only strain showing a large difference was NCTC7973a, which differed by about $8 \% \mathrm{~S}$ from the more recently acquired strain. As the strains were all given study reference (C) numbers (listed in Table I) and all bench work was done using the $\mathrm{C}$ numbers only, I was unaware of their true identity and thus bias was reduced to a minimum.

Test reproducibility. The effect of errors in microbiological tests on numerical taxonomic similarities has been discussed by Sneath \& Johnson (I972). All tests were repeated twice on the same basal medium; in addition, some were repeated more frequently on the same medium, while others were repeated using a different basal medium or different conditions of incubation.

Some tests, e.g. degree of acid fastness and oxidase reaction, were bad tests in that very slight differences in basal media or technique gave different results; however, the reproducibility of the majority of the tests fell within the limits discussed by Sneath \& Johnson (1972). The average percentage of discrepancies, $p$, was $2.4 \%$ and therefore would introduce little distortion into the numerical analyses as noted by Sneath \& Johnson (1972).

\section{DISCUSSION}

The composition of the three broad similarity areas, their relationship to each other and the taxonomic significance of the groupings will be discussed separately.

\section{Area I}

The grouping of the species Microbacterium thermosphactum and the genera Listeria and Erysipelothrix with representatives of the Lactobacillaceae confirms the evidence from previous numerical taxonomic studies (Davis et al. 1969; Stuart \& Pease, 1972; Wilkinson, 1973) and that derived from enzyme and DNA base ratio studies (Collins-Thompson et al. 1972; Trivett \& Meyer, 197I; Stuart \& Welshimer, 1973; Flossman \& Erler, 1972) that these bacteria show a closer relationship to the Lactobacillaceae than to the Corynebacteriaceae. The characteristics of the important taxa are given in Table 3.

Microbacterium thermosphactum. Microbacterium thermosphactum strains, together with the atypical lactobacilli of Thornley \& Sharpe's (I959) group I, form a well defined cluster AI $(>90 \%$ S) which joins the two Lactobacillus spp. at $83 \%$ S. As pointed out by other workers (see Collins-Thompson et al. 1972) Micro. thermosphactum is quite different from the other species of the genus Microbacterium (see below), and on the basis of the present study is sufficiently distinct from a number of other closely allied genera to merit genus status.

Listeria. Listeria monocytogenes strains also form a distinct cluster, $\mathrm{A}_{3}(>90 \% \mathrm{~S})$, joining the one strain of List. grayi at $87 \% \mathrm{~S}$ and one strain (LTRS MT36) of Thornley \& Sharpe's group III atypical lactobacilli at $84 \% \mathrm{~S}$, but quite distinct from both Micro. thermosphactum and Erysipelothrix. Because only one strain of List. grayi was included and no strains of List. murrayi were available at the start of this study, little can be said about the status of the latter two species or whether or not they are distinct enough from List. monocytogenes to be considered as separate species as suggested by Stuart \& Welshimer (1973). The results based on the one strain of List. grayi indicate that this species is worthy of separate species status in the genus Listeria. This is in accord with the findings of Wilkinson (1973).

The association of the atypical Lactobacillus strain (LTRS MT36) with this group is 
Table 3. Characteristics of subgroups in clusters $A$ and $B$ as percentages of positive reactions

Information derived from material presented in Figs. I and 3.

\begin{tabular}{|c|c|c|c|c|c|}
\hline & $\begin{array}{c}\text { Micro. thermo- } \\
\text { sphactum } \\
\text { AI }\end{array}$ & $\begin{array}{l}\text { Lactobacillus } \\
\quad \text { A2 }\end{array}$ & $\begin{array}{l}\text { Listeria } \\
\quad \mathrm{A}_{3}\end{array}$ & $\begin{array}{c}\text { Strep. faecalis } \\
\mathrm{A}_{4}\end{array}$ & $\begin{array}{c}\text { Erysipelothrix } \\
\text { Streptococcus } \\
\text { B }\end{array}$ \\
\hline No. of strains tested & 6 & 3 & 23 & 3 & 6 \\
\hline \multicolumn{6}{|l|}{ Colonial morphology } \\
\hline Colony elevation flat & 0 & 0 & 0 & 0 & 57 \\
\hline Colony elevation raised & I7 & 0 & 4 & o & 0 \\
\hline Colony elevation convex & 83 & 100 & 96 & 100 & 43 \\
\hline Colony elevation irregular & 50 & 0 & 0 & 0 & 0 \\
\hline Colony mucoid & 0 & o & o & 0 & 0 \\
\hline \multicolumn{6}{|l|}{ Colony leaves impression in } \\
\hline agar & o & 100 & 57 & 100 & 0 \\
\hline Colony margin entire & 50 & 100 & $9 \mathrm{I}$ & 100 & 43 \\
\hline Colony margin irregular & 50 & 0 & 9 & 0 & 57 \\
\hline Colony easily emulsified & 100 & 100 & 100 & 100 & 100 \\
\hline Colony coarse suspension & 0 & 0 & 0 & o & 0 \\
\hline Colony violet/blue & 0 & 0 & 0 & o & 0 \\
\hline Colony pink/red & o & 0 & o & o & 0 \\
\hline Colony yellow/orange/brown & o & 0 & 0 & o & 0 \\
\hline Colony cream/grey/white & 100 & 100 & 100 & 100 & 100 \\
\hline Exopigment, water-soluble & 0 & 0 & 0 & 0 & 0 \\
\hline Crystals formed & 0 & 0 & 0 & 0 & 0 \\
\hline Mycelium formed & 0 & 0 & 0 & o & 0 \\
\hline Aerial hyphae & 0 & 0 & 0 & 0 & 0 \\
\hline \multicolumn{6}{|l|}{ Blue/green irridescence } \\
\hline (Henry technique) & 0 & 0 & 83 & 0 & 0 \\
\hline \multicolumn{6}{|l|}{ Stained preparations } \\
\hline Rods and filaments & 83 & 33 & 43 & 0 & $7 \mathrm{I}$ \\
\hline Rods and cocci & 0 & 0 & 0 & 0 & 0 \\
\hline Rods only & 17 & 67 & 57 & 0 & 0 \\
\hline Branching present & 0 & o & 0 & 0 & 0 \\
\hline Mycelium present & o & 0 & 0 & 0 & 0 \\
\hline Cystites & 0 & 0 & 0 & 0 & 0 \\
\hline Chains formed & 100 & 100 & 100 & 100 & 100 \\
\hline Barred staining & 67 & 100 & 96 & 0 & $7 \mathrm{I}$ \\
\hline Bipolar staining & o & o & 0 & o & 0 \\
\hline Rods $<2 \mu$ m long & 100 & 100 & 100 & 100 & 100 \\
\hline Rods $>2 \mu \mathrm{m}$ long & 0 & 0 & o & o & 0 \\
\hline Acid fastness & 0 & 0 & o & 0 & 0 \\
\hline Homogeneous growth in SEB & 100 & 100 & 100 & 100 & 29 \\
\hline Collar/pellicle in SEB & 0 & 0 & o & 0 & 0 \\
\hline Growth on blood agar & 100 & 100 & 100 & 100 & 100 \\
\hline$\beta$-Haemolysis & 0 & o & 9I & 0 & 17 \\
\hline Greening of blood & 100 & 100 & 4 & 0 & 0 \\
\hline Motility & o & 0 & 83 & 100 & 0 \\
\hline Microcolonies & 0 & 0 & 0 & 13 & 14 \\
\hline Flagella & 0 & 0 & 70 & 67 & 0 \\
\hline \multicolumn{6}{|l|}{ Growth at } \\
\hline $4^{\circ} \mathrm{C}$ & 100 & 100 & 100 & 100 & 0 \\
\hline $10{ }^{\circ} \mathrm{C}$ & 83 & 100 & 100 & 100 & $7 \mathrm{I}$ \\
\hline $25^{\circ} \mathrm{C}$ & 100 & 100 & 100 & 100 & IOO \\
\hline $30^{\circ} \mathrm{C}$ & 100 & 100 & 100 & 100 & 100 \\
\hline $37^{\circ} \mathrm{C}$ & 17 & 100 & 100 & 100 & 100 \\
\hline $45^{\circ} \mathrm{C}$ & I7 & 33 & 4 & 100 & o \\
\hline $50^{\circ} \mathrm{C}$ & 0 & 0 & 0 & 0 & o \\
\hline Survival at $60^{\circ} \mathrm{C}$ for $30 \mathrm{~min}$ & 0 & 0 & 0 & 100 & 0 \\
\hline Anaerobic growth & 100 & 100 & 100 & 100 & 100 \\
\hline
\end{tabular}


Table 3 (cont.)

Micro thermosphactum

Lactobacillus

Catalase

Benzidine

Oxidase

$$
\text { A I }
$$

A2

Acid from

Arabinose

Xylose

Rhamnose

Fructose

Galactose

Glucose

Aerobic

Anaerobic

Mannose

Cellobiose

Lactose

Sucrose

Maltose

Melezitose

Raffinose

Melibiose

Sorbose

Salicin

Adonitol

Inositol

Dulcitol

Mannitol

Glycerol

Sorbitol

Hydrolysis tests

Aesculin blackening

Aesculin loss purple fluorescence

Arginine

Arginine (Thornley)

Casein

Cellulose

Chitin

Gelatin

DNA

Hippurate

Tween 20 clearing

Tween $20 \mathrm{ppt}$

Tween 40 clearing

Tween $40 \mathrm{ppt}$

Tween 60 clearing

Tween $60 \mathrm{ppt}$

Tween 80 clearing

Tween $80 \mathrm{ppt}$

Tyrosine

Pigment from tyrosine

Xanthine

Starch

Starch (in $10 \% \mathrm{CO}_{2}$ )

Sole carbon source

Citrate

Gluconate

Glucose

100
17

o

100

100

83

IOO

100

100

I 00

100

100

100

100

100

100

17

100

0

100

IOO

100

83

100

100

I 00

83

67

I 6

0

0

o

0

o

0

0

0

o

o

0
17

0

0

0

0

○

0

17

100

\section{0}

0

0

I 00

100

67

IOO

100

100

100

100

100

100

100

100

100

67

I 00

33

IOO

100

67

0

67

I0O

100

100

33

33

0

o

o

o

0

67

o

0

33

0

0

67

o

o

o

0

o

o

$$
\text { o }
$$

0

100

I 00
Erysipelothrix

Listeria Strep. faecalis Streptococcus

$\begin{array}{lll}\mathrm{A}_{3} & \mathrm{~A}_{4} & \mathrm{~B}\end{array}$

9 I

13

0

100

87

100

100

100

100

96

96

100

74

0

0

IOO

o

0
9

0

4

100

13

100

I0O

0

I 3

0

o

0

o

0
100

100
67

0

0

IOO

100

67

100

100

0

o

$100 \quad 100$

$100 \quad 100$

$100 \quad 100$

$100 \quad 29$

$100 \quad 100$

$100 \quad 29$

IOO 100

$100 \quad 29$

0

0
33

100

100

67

0

100

IOO

100

100

100

100

67

0

o

0

0

IOO

o

o

100

67

I0O

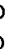

86

14

14

100

29

I 4

I 4

I 4

I 4

0

0

I 4

o

I 4

I 4

29

57

57

29

0

0

0

29

57

0

0

o

0

29

0

0

o

0

0

o

100

100

100 
Table 3 (cont.)

\begin{tabular}{|c|c|c|c|c|c|}
\hline & $\begin{array}{c}\text { Micro. thermo- } \\
\text { sphactum } \\
\text { AI }\end{array}$ & $\begin{array}{l}\text { Lactobacillus } \\
\quad \text { A2 }\end{array}$ & $\begin{array}{l}\text { Listeria } \\
\quad \mathrm{A}_{3}\end{array}$ & $\begin{array}{c}\text { Strep. faecalis } \\
\mathrm{A}_{4}\end{array}$ & $\begin{array}{c}\text { Erysipelot } \\
\text { Streptococ } \\
\text { B }\end{array}$ \\
\hline \multicolumn{6}{|l|}{ Sole carbon source (cont.) } \\
\hline Hippurate & 0 & 0 & 0 & 0 & 0 \\
\hline Malate & 0 & 0 & 0 & 100 & 0 \\
\hline Propionate & 0 & 0 & 0 & o & o \\
\hline Pyruvate & 0 & 0 & 4 & 100 & 0 \\
\hline Succinate & 0 & 0 & 0 & o & 0 \\
\hline \multicolumn{6}{|l|}{ Sole nitrogen source } \\
\hline$\left(\mathrm{NH}_{4}\right)_{2} \mathrm{SO}_{4}$ & 0 & o & 0 & 0 & 0 \\
\hline $\mathrm{KNO}_{3}$ & 0 & 0 & 0 & 0 & 0 \\
\hline $\mathrm{KNO}_{3}+$ Casamino acid & 0 & 33 & 57 & 100 & 0 \\
\hline \multicolumn{6}{|l|}{$\begin{array}{l}\text { Growth in presence of } \\
\mathrm{NaCl}\end{array}$} \\
\hline $5 \%(w / v)$ & 100 & 0 & 100 & 100 & 29 \\
\hline $10 \%(w / v)$ & 83 & 33 & 87 & 0 & 0 \\
\hline \multicolumn{6}{|l|}{ Thallous acetate } \\
\hline $0.01 \%(w / v)$ & 100 & 100 & 100 & 100 & 100 \\
\hline $0.02 \%(w / v)$ & 100 & 100 & 100 & 100 & 86 \\
\hline $0.03 \%(w / v)$ & 100 & 100 & 100 & 100 & 86 \\
\hline \multicolumn{6}{|l|}{ Sodium azide } \\
\hline $0.01 \%(w / v)$ & 0 & 67 & 26 & 100 & 100 \\
\hline $0.02 \%(\mathrm{w} / \mathrm{v})$ & 0 & 67 & 4 & 100 & 43 \\
\hline $0.05 \%(w / v)$ & 0 & 67 & 4 & 100 & 43 \\
\hline \multicolumn{6}{|l|}{ Potassium thiocyanate } \\
\hline $2 \cdot 5 \%(\mathrm{w} / \mathrm{v})$ & 83 & 33 & 96 & 100 & I 4 \\
\hline $3.75 \%(w / v)$ & 16 & 33 & 96 & 33 & 0 \\
\hline $4.5 \%(w / v)$ & 0 & 33 & 96 & 33 & 0 \\
\hline \multicolumn{6}{|l|}{ Tetrazolium } \\
\hline $0.01 \%(w / v)$ & IOO & 100 & 100 & 100 & $7 \mathrm{I}$ \\
\hline Reduction $0.01 \%(\mathrm{w} / \mathrm{v})$ & 50 & 0 & 0 & 67 & 0 \\
\hline $0.1 \%(\mathrm{~W} / \mathrm{V})$ & 0 & 100 & $9 I$ & 100 & 0 \\
\hline Reduction $0.1 \%(w / v)$ & 0 & 33 & 87 & 100 & 0 \\
\hline \multicolumn{6}{|l|}{ Potassium tellurite } \\
\hline $0.01 \%(w / v)$ & 0 & 33 & 96 & 100 & 100 \\
\hline Reduction $0.01 \%(w / v)$ & 0 & 33 & 96 & 100 & 100 \\
\hline $0.025 \%(w / v)$ & 0 & 0 & 87 & 100 & 100 \\
\hline Reduction $0.025 \%(\mathrm{w} / \mathrm{v})$ & 0 & o & 87 & 100 & 100 \\
\hline $0.05 \%(\mathrm{w} / \mathrm{v})$ & 0 & o & 87 & 100 & 86 \\
\hline Reduction $0.05 \%(\mathrm{w} / \mathrm{v})$ & 0 & 0 & 87 & 100 & 86 \\
\hline Lysis by lysozyme & 100 & 33 & 100 & 100 & 0 \\
\hline Lysis by lysozyme + EDTA & IOO & 33 & 100 & 100 & 0 \\
\hline \multicolumn{6}{|l|}{ Sensitivity to* } \\
\hline Penicillin $(\mathrm{H})$ & IOO & 67 & 100 & 100 & 100 \\
\hline Streptomycin $(\mathrm{H})$ & 0 & 100 & 100 & 100 & 71 \\
\hline Chloramphenicol $(\mathrm{H})$ & 100 & 100 & 100 & 100 & 100 \\
\hline Aureomycin $(\mathrm{H})$ & 100 & 100 & 96 & 100 & 100 \\
\hline Terramycin $(\mathrm{H})$ & 100 & 100 & 96 & 100 & 86 \\
\hline Erythromycin (H) & 100 & 100 & 100 & 100 & 86 \\
\hline Tetracycline $(\mathrm{H})$ & 100 & 100 & 96 & 100 & 100 \\
\hline Sulphonamide $(\mathrm{H})$ & 0 & 0 & 0 & 0 & o \\
\hline Ledermycin $(\mathrm{H})$ & 100 & 100 & 100 & 100 & 86 \\
\hline Celbenin & 0 & 0 & 43 & 0 & 86 \\
\hline Kanamycin $(\mathrm{H})$ & 100 & 67 & 100 & 33 & 0 \\
\hline Penbritin $(\mathrm{H})$ & 100 & IOO & 100 & 100 & 86 \\
\hline Spiramycin (L) & 100 & 100 & 100 & 33 & 71 \\
\hline Vancomycin (L) & 100 & 33 & 100 & 100 & 57 \\
\hline Paromomycin $(\mathrm{H})$ & 100 & 33 & 100 & 100 & 0 \\
\hline
\end{tabular}

* (H), high potency; (L), low potency. 
Table 3 (cont.)

\begin{tabular}{|c|c|c|c|c|c|}
\hline & $\begin{array}{c}\text { Micro, thermo- } \\
\text { sphactum } \\
\text { AI }\end{array}$ & $\begin{array}{c}\text { Lactobacillus } \\
\mathrm{A}_{2}\end{array}$ & $\begin{array}{c}\text { Listeria } \\
\mathrm{A}_{3}\end{array}$ & $\begin{array}{c}\text { Strep. faecalis } \\
\mathrm{A}_{4}\end{array}$ & $\begin{array}{c}\text { Erysipelothrix } \\
\text { Streptococcus } \\
\text { B }\end{array}$ \\
\hline \multicolumn{6}{|l|}{ Sensitivity to (cont.) } \\
\hline Fucidin (L) & 100 & 0 & 30 & o & 86 \\
\hline Neomycin $(\mathrm{H})$ & 100 & 67 & 100 & 67 & I 4 \\
\hline Bacitracin & 100 & 100 & 100 & 100 & 100 \\
\hline Novibiocin $(\mathrm{H})$ & 100 & 100 & IOO & 100 & 29 \\
\hline Oleandomycin $(\mathrm{H})$ & 100 & 100 & 100 & 100 & 71 \\
\hline Colomycin (L) & 67 & 0 & 4 & 0 & 0 \\
\hline Polymyxin (L) & 100 & 67 & 100 & o & 29 \\
\hline Nitrofurantoin & 100 & 67 & 87 & 33 & 43 \\
\hline Methyl red & 100 & 100 & 100 & 100 & 71 \\
\hline Voges Proskauer & 100 & 100 & 100 & 100 & 0 \\
\hline Egg yolk ppt & 0 & 67 & $6 \mathrm{I}$ & 33 & 14 \\
\hline Egg yolk clearing & o & 0 & o & 0 & 0 \\
\hline \multicolumn{6}{|l|}{ Litmus milk } \\
\hline Acid production & 0 & 100 & 96 & 100 & 100 \\
\hline Alkaline production & 0 & 0 & 0 & 0 & 0 \\
\hline Coagulation & 0 & 67 & 0 & 100 & o \\
\hline Digestion & 0 & 0 & 0 & 67 & o \\
\hline Peptonization & 0 & 0 & 0 & 0 & 0 \\
\hline Reduction & 0 & 33 & 9 & 100 & 29 \\
\hline Reduction $\mathrm{NO}_{3} \rightarrow \mathrm{NO}_{2}$ & 0 & 0 & 0 & 0 & 0 \\
\hline Reduction $\mathrm{NO}_{3} \rightarrow \mathrm{N}_{2}$ & o & o & 0 & 0 & o \\
\hline Reduction $\mathrm{NO}_{3}$ beyond $\mathrm{N}_{2}$ & 0 & 0 & o & 0 & 0 \\
\hline Production $\mathrm{H}_{2} \mathrm{~S}$ & 0 & 0 & o & 0 & 0 \\
\hline Urease & 0 & 0 & o & 0 & 0 \\
\hline Sulphatase & 0 & o & 0 & o & o \\
\hline Phosphatase & 100 & 100 & 96 & 100 & 29 \\
\hline Ammonia from SEB & 0 & 0 & o & 0 & 0 \\
\hline
\end{tabular}

interesting, but no serological relationships could be detected between this strain and antisera prepared against List. monocytogenes, List. grayi or List. murrayi.

As noted by Stuart \& Welshimer (1973) List. denitrificans is quite different from the other members of the genus and in the present study it groups loosely with some Corynebacterium strains isolated from poultry and Arthrobacter spp. (AI37/68 and Brzin) isolated from the human throat. This cluster may well form the basis of an as yet unrecognized taxon.

Erysipelothrix. The four recently isolated strains of $E$. rhusiopathiae grouped in a tight cluster at about $93 \% \mathrm{~S}$ but the strain NCTC8163 showed a number of differences which resulted in an apparently closer similarity of this strain to a Streptococcus sp. of serological group G. Of interest is the association of Strep. faecalis strains with the LactobacillusListeria-Micro. thermosphactum group, while the one strain of Strep. pyogenes and the Streptococcus strain of serological group $G$ showed a closer association with the Erysipelothrix cluster. A similar close association between Erysipelothrix and Streptococcus was noted by Davis et al. (1969), but these authors doubted the validity of their results because of the limitations imposed when a variety of different bacteria are studied under one set of conditions. Although the \% guanine-cytosine (GC) base ratio of Erysipelothrix ( 36 to 38 ; Flossmann \& Erler, 1972) is in the same range as that of the streptococci, the cell walls of Erysipelothrix contain diaminopimelic acid which has never been detected in the cell walls of streptococci.

Classically, the presence of cytochromes and catalase have excluded bacteria from the Lactobacillaceae, but it is now recognized that some Lactobacillus species are catalase 
positive (Dacre \& Sharpe, I956; Vankova, 1957; Whittenbury, 1964) and in our experience Listeria strains which are normally strongly catalase positive when grown on rich laboratory media are catalase negative if grown on a medium low in yeast extract although they grow equally well. We were, however, able spectrophotometrically to demonstrate low levels of cytochromes in List. monocytogenes (Jones, unpublished) though Trivett \& Meyer (1971) reported the absence of cytochromes in Listeria. Microbacterium thermosphactum, although catalase positive, frequently gives an equivocal benzidine reaction. However, this is also dependent on the composition of the growth medium, and using spectrophotometric techniques Davidson, Mobbs \& Stubbs (1968) demonstrated a full cytochrome system in these bacteria. No catalase or cytochromes have been detected in Erysipelothrix.

A strong case can be made for the inclusion of Erysipelothrix, Listeria and Micro. thermosphactum in the family Lactobacillaceae. It can be argued that the inclusion of these taxa in this family makes an already large family unwieldy. The alternative is to create a new family. However, this seems premature because there has been no comprehensive comparison of Erysipelothrix, Listeria, Micro. thermosphactum and the interesting atypical lactobacilli of Thornley \& Sharpe (I959) with all the genera presently included in the Lactobacillaceae. Such a study should be performed before any 'family of convenience' is created to accommodate refugees from other bacterial families. The study of Wilkinson (I973), which covers a great deal but not all of this area, is in accord with this latter view.

\section{Area II}

This area consists of three main phenons C, D and E (Figs. I and 3). Of the eight subgroups, four can be equated with the established genera Corynebacterium, Cellulomonas, Microbacterium and Propionibacterium, two are centred around the species Cor. pyogenes and List. denitrificans, one contains the cellulolytic nocardias, and one the 'throat' arthrobacters.

As can be seen from Table 2, there is no one character or set of characters which distinguishes area I from area II. There are catalase- and cytochome-containing strains in both areas, although they predominate in area II. A character which seems potentially useful for the characterization of the areas is the mode of division of the bacteria. Chain formation is less common in area II, whereas the snapping type of cell division characteristic of area II, resulting in the production of $\mathrm{V}$ and Chinese-letter forms, is not typical of area I. However, in our experience this character is influenced by the mode of culture and in a routine laboratory where an unknown bacterium would be grown on solid routine laboratory media a strain of Lactobacillus can exhibit typical V forms (and see Streptobacterium plantarum No. 5 of Orla-Jensen, I919; Plate XLIII). The characteristics of the important taxa are given in Table 4 .

Corynebacterium. There is general if not universal agreement that the genus Corynebacterium includes the type species Cor. diphtheriae and its close relatives (Jensen, 1952; Barksdale, 1970; Harrington, I966; Yamada \& Komagata, I972 b). To this 'animal group' have been added various other species, e.g. Cor. equi, Cor. pyogenes and Cor. fascians, but doubts have been expressed on whether some or any of them belong to the genus (Jensen, I952; Barksdale, 1970; Lelliott, 1966; Robinson, I966a). On the other hand there is a growing opinion that the species Micro. flavum should be reclassified in the genus Corynebacterium (Collins-Thompson et al. 1972). The grouping of Cor. diphtheriae and the other animal species plus Micro. flavum in subgroup $\mathrm{Cr}_{\mathrm{I}}$ of the present study is in keeping with the reported $\%$ GC base ratios (Bouisset, Breuillard \& Michel, 1963; Bousfield, 1972; Collins-Thompson et al. 1972). Support also comes from the numerical taxonomic study of Harrington (1966) who found a group containing several animal coryneforms, but Cor. murium was related 
at a lower $\% \mathrm{~S}$ value, as were Cor. pyogenes and Cor. haemolyticum. The close association of Cor. ovis with Cor. diphtheriae is in accord with the report of Barksdale (1970) that when lysogenized with a tox $x^{+}$phage Cor. ovis synthesizes diphtheria toxin. However, Barksdale (1970) suggested the retention of all the species:grouped in subgroup $\mathrm{Cl}_{1}$ of the present study, plus Cor. equi, in the genus Corynebacterium, and Yamada \& Komogata (1972 b) also included Cor. equi and Cor. fascians in the genus. This is the opposite of the results of the present study, where Cor. equi and Cor. fascians showed a relationship to the "Mycobacterium rhodochrous' group. Additionally, both these species contain a lipid constituent which Goodfellow, Minnikin, Patel \& Modarska_(1973) consider to be characteristic of the 'Myco. rhodochrous' complex.

Microbacterium flavum. The association of Micro. flavum with the animal corynebacteria is in agreement with data from numerical studies (Bousfield, 1972; Stuart \& Pease, 1972), cell wall studies (Cummins \& Harris, 1956; Robinson, I966 b, $c$; Schleifer, 1970), electrophoretic patterns of catalases and esterases (Robinson, I966a, $c$; Collins-Thompson et al. I972), and metabolic pathways and \% GC DNA'base ratio (Collins-Thompson et al. 1972).

Microbacterium lacticum - Brevibacterium imperiale. Microbacterium lacticum, the type species of the genus Microbacterium, is far more closely related to Micro. flavum than either are to Micro. thermosphactum. Indeed, there have been a number of suggestions that Micro. lacticum should be reclassified as Corynebacterium (Abd-el-Malek \& Gibson, 1952; Jensen, 1932; Collins-Thompson et al. I972). However, in the present study Micro. lacticum clusters with $\mathrm{Br}$. imperiale (DI). This separation from the animal corynebacteria is in keeping with the reported $\%$ GC DNA base ratios of 63 (Collins-Thompson et al. 1972) and 69.3 (Yamada \& Komogata, $1970 b$ ), with bicchemical and serological studies (Robinson, $1966 b, c$ ), and with the numerical taxonomic studies of Davis et al. (I969), Stuart \& Pease (1972) and Bousfield (1972).

The close association between Micro. lacticum and Br. imperiale noted in Figs. I and 3 is in keeping with the results of Yamada \& Komagata ( $1972 b)$. It is possible that this small cluster is synonymous with the genus Microbacterium (Orla-Jensen, I9I9) and the proposal to omit the genus from the forthcoming edition of Bergey's Manual (Collins-Thompson et al. I972) is premature.

Corynebacterium pyogenes. The generic position of Cor. pyogenes has been questioned for some time. A number of workers have presented evidence of a close affinity to the streptococci (Barksdale, Li, Cummins \& Harris, I957; Sneath \& Cowan, 1958; Barksdale, 1970). Stuart \& Pease (1972), in their computation of similarity between coryneform bacteria based on 'general characters', also found a close association between Cor. pyogenes and streptococci, but in the same study the computation of similarity based on physiological characteristics indicated a closer relationship to the animal corynebacteria. Bousfield (1972) noted a relationship between Cor. pyogenes and Listeria and Erysipelothrix, all of which showed some relationship to the animal corynebacteria. Harrington (1966) noted that Cor. pyogenes and Cor. haemolyticum (which is probably a haemolytic variant of Cor. pyogenes; Barksdale et al. 1957) clustered together and were quite distinct from the main group of animal corynebacteria.

In the present study the two strains of Cor. pyogenes differed slightly (Figs. I and 3), one showing a closer relationship to $B r$. incertum (which is haemolytic), the other showing a closer relationship to Cor. haemolyticum. Corynebacterium pyogenes is probably a variable species containing several subgroups (Roberts, 1968).

'Bacterium eurydice', which clusters with the Cor. pyogenes group, is an interesting bacterium whose relationship, if any, to Strep. pluton is not clear (Bailey, 1957, 1960, 1963). 
Table 4. Characteristics of subgroups in clusters $C, D$ and $E$ as percentages of positive reactions

Cor. Cor.

diphtheriae pyogenes Micro.

related related

$\begin{array}{cc}\text { bacteria } & \text { bacteria } \\ \mathrm{C}_{1} & \mathrm{C}_{2} * \dagger\end{array}$

lacticum

$\mathrm{Br} . \quad$ N. cellulans Celluloimperiale N.turbata monas

Di* D2

I 3

No. of strains tested

Colonial morphology

Colony elevation flat

Colony elevation raised

Colony elevation convex

Colony elevation irregular

Colony mucoid

Colony leaves impres-

sion in agar

Colony margin entire

Colony margin irregular

Colony easily emulsified

Colony coarse suspension

Colony violet/blue

Colony pink/red

Colony yellow/orange/ brown

Colony cream/grey/ white

Exopigment, water soluble

Crystals formed

Mycelium formed

Aerial hyphae

Blue/green irridescence (Henry technique)

Stained preparations

Rods and filaments

Rods and cocci

Rods only

Branching present

Mycelium present

Cystites

Chains formed

Barred staining

Bipolar staining

Rods $<2 \mu \mathrm{m}$ long

Rods $>2 \mu \mathrm{m}$ long

Acid fastness

Homogeneous growth in SEB

Collar/pellicle in SEB

Growth on blood agar

$\beta$-Haemolysis

Greening of blood

Motility

Microcolonies

Flagella

$\begin{array}{rrrr}13 & 8 & 3 & \\ 0 & 0 & 0 & \\ 0 & 25 & 0 & \\ 100 & 75 & 100 & 100 \\ 0 & 0 & 0 & \\ 0 & 0 & 0 & \\ 54 & 38 & 33 & 100 \\ 100 & 100 & 100 & 20 \\ 0 & 0 & 0 & 80 \\ 92 & 100 & 100 & 100\end{array}$

D3*

44
100
0
100

$85 \quad 100 \quad 33$

$8 \quad 0$

$\begin{array}{lll}0 & 0 & 22\end{array}$

$0 \quad 0$

$\begin{array}{ll}0 & 0 \\ 0 & 0\end{array}$

$$
\text { o }
$$$$
0
$$$$
\begin{array}{ll}
0 & 0 \\
0 & 0
\end{array}
$$$$
00
$$$$
\text { o }
$$$$
\text { o }
$$$$
\text { o }
$$

0

0
I 5
85

$\begin{array}{rr}85 & 75 \\ 0 & 0\end{array}$

00

$\begin{array}{rr}0 & 0 \\ 3 I & 75\end{array}$

2355

$\begin{array}{ll}69 & 38\end{array}$$$
100 \quad 100
$$$$
0 \quad 0
$$

o 13

$\begin{array}{rr}92 & 100 \\ 3 \mathrm{I} & \\ 100 & 100 \\ 23 & 25 \\ 8 & \\ 0 & \\ 0 & \\ 0 & \end{array}$

$\begin{array}{rr}100 & 100 \\ 0 & 0 \\ 100 & 100 \\ 25 & 0 \\ 0 & 0 \\ 13 & 33 \\ 0 & 0 \\ 0 & 33\end{array}$

$\begin{array}{rr}0 & 0 \\ 100 & 56 \\ 0 & 44 \\ 80 & 56 \\ 60 & 0 \\ 0 & 0 \\ 0 & 11 \\ 100 & 89 \\ 0 & 0 \\ 80 & 44 \\ 20 & 56 \\ 60 & 11 \\ & \\ 100 & 100 \\ 0 & 22 \\ 100 & 100 \\ 0 & 0 \\ 60 & 0 \\ 20 & 67 \\ 0 & 0 \\ 0 & 22\end{array}$

Propioni-

List.

denitrifi-

cans and

coryne-

EI*

Es and

$\begin{array}{rrrr}5 & 9 & 5 & 7 \\ 0 & 0 & 0 & 29 \\ 0 & \text { II } & 0 & 14 \\ 100 & 89 & 100 & 57 \\ 0 & 0 & 0 & 0 \\ 0 & \text { II } & 0 & 0\end{array}$

$40 \quad 14$

7 I

29

$7 \mathrm{I}$

$\begin{array}{rr}20 & 29 \\ 0 & 0 \\ 0 & 0\end{array}$

$\begin{array}{rr}20 & 29 \\ 0 & 0 \\ 0 & 0\end{array}$

$20 \quad 43$

57

$100 \quad 100 \quad 20$

80

7

29

14

57

$$
\text { o }
$$

(2)

$\begin{array}{rr}0 & 29 \\ 80 & 7 I\end{array}$

$\begin{array}{llll}0 & 0 & 80 & 57\end{array}$

0

$$
0
$$$$
\text { o }
$$$$
0
$$$$
0 \quad 0
$$

$\begin{array}{rr}0 & 29 \\ 100 & 86 \\ 0 & 14 \\ 40 & 14 \\ 0 & 0 \\ 40 & 57 \\ 20 & 29 \\ 100 & 86 \\ 0 & 0 \\ 40 & 43 \\ 60 & 57 \\ 0 & 29 \\ & \\ 80 & 100 \\ 0 & 29 \\ 100 & 100 \\ 0 & 0 \\ 0 & 57 \\ 0 & 14 \\ 0 & 0 \\ 0 & 14\end{array}$

* From material presented in Figs. I and 3.

$\uparrow$ Agromyces ramosus and Arthrobacter terregens not included.

\$ From material presented in Figs. 2 and 4 . 
Table 4 (cont.)

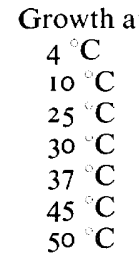

Surivival at $60 \mathrm{C}$ for $30 \mathrm{~min}$

Anaerobic growth

\section{Catalase}

Benzidine

Oxidase

Acid from

Arabinose

Xylose

Rhamnose

Fructose

Galactose

Glucose Aerobic Anaerobic

Mannose

Cellobiose

Lactose

Sucrose

Maltose

Melezitose

Raffinose

Melibiose

Sorbose

Salicin

Adonitol

Inositol

Dulcitol

Mannitol

Glycerol

Sorbitol

Hydrolysis tests

Aesculin blackening

Aesculin loss purple fluorescence

Arginine
Arginine (Thornley)

Casein

Cellulose

Chitin

Gelatin

DNA

Hippurate

Tween 20 clearing

Tween $20 \mathrm{ppt}$

Tween 40 clearing

Tween $40 \mathrm{ppt}$
Cor. Cor.

diphtheriae pyogenes Micro.

and and lacticum

$\begin{array}{ccccccc}\text { and } & \text { and } & \text { lacticum } & & & \text { cans and } \\ \text { related } & \text { related } & \text { Br. } & \text { N. cellulans } & \text { Cellulo- } & \text { Propioni- } & \text { coryne- } \\ \text { bacteria } & \text { bacteria } & \text { imperiale } & \text { N.turbata } & \text { monas } & \text { bacteria } & \text { forms }\end{array}$

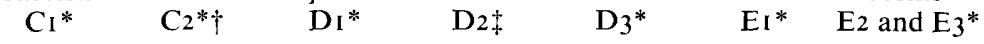

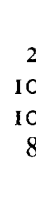

I3
13
88
100
100
0
0

$\begin{array}{rr}100 & 100 \\ 100 & 100 \\ 100 & 100 \\ 100 & 100 \\ 100 & 20 \\ 0 & 0 \\ 0 & 0\end{array}$

44
89
100
100
67
0
0

60

$60 \quad 43$

23

100

100

85

0

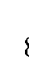

85

100

100

I 8

0
50
13
13
0

66

33

I00

100

80

80
100

100

40

II
56
100
89
22

100

$13 \quad 33$

$\begin{array}{rr}25 & 33 \\ 13 & 0\end{array}$

I 3

100

100

60

40

63

100

100

$100 \quad 100$

100

100

66

66

66

100

o

33

0

0
100

100

o

0

66

33

66

100

60

100

60

100

60

60

40

20

0

100

0

o

0

0

80

100

100

33

100

33

66

$89 \quad 100$

100

40

100

100

List.

dentrifi-

cans and

22

100

78

100

100

89

89

56

100

100

33

22

33

0

100

I

I I

0
22

22
44

I I

100

100

IOO

60

80
100

100
100

100
100

40

100

$\circ$

60

100

100

6

60

100

100

43

57

100

43

0

0

0

100

100

57

0

57

57

43

I 00

86

100

100

100

71

57

86

100

43

I4

57

0

57

43

0

71

100

29

89

100

100

100

100

89

100
100

100

7 I

29

29

0

O

14

57

14

14

29

57 


\section{Table 4 (cont.)}

\begin{tabular}{|c|c|c|c|c|c|c|c|}
\hline & $\begin{array}{l}\text { Cor. } \\
\text { diphtheriae } \\
\text { and } \\
\text { related } \\
\text { bacteria } \\
\text { CI }^{*}\end{array}$ & $\begin{array}{c}\text { Cor. } \\
\text { pyogenes } \\
\text { and } \\
\text { related } \\
\text { bacteria } \\
\mathrm{C}^{*+}\end{array}$ & $\begin{array}{c}\text { Micro. } \\
\text { lacticum } \\
\text { Br. } \\
\text { imperiale } \\
\text { DI }^{*}\end{array}$ & $\begin{array}{c}\text { N. cellulans } \\
\text { N. turbata } \\
\text { D2 } \div\end{array}$ & $\begin{array}{c}\text { Cellulo- } \\
\text { monas } \\
\text { D3 }^{*}\end{array}$ & $\begin{array}{c}\text { Propioni- } \\
\text { bacteria } \\
\text { EI }^{*}\end{array}$ & $\begin{array}{c}\text { List. } \\
\text { denitrifi- } \\
\text { cans } \text { and } \\
\text { coryne- } \\
\text { forms } \\
\mathrm{E}_{2} \text { and } \mathrm{E}_{3}{ }^{*}\end{array}$ \\
\hline \multicolumn{8}{|l|}{ Hydrolysis test (cont.) } \\
\hline Tween 60 clearing & 0 & 0 & 100 & 100 & 89 & 40 & 14 \\
\hline Tween $60 \mathrm{ppt}$ & 100 & 63 & 33 & 100 & 89 & 40 & 29 \\
\hline Tween 80 clearing & 23 & 0 & 0 & 0 & 0 & 0 & 14 \\
\hline Tween $80 \mathrm{ppt}$ & 85 & 13 & 0 & 40 & 89 & 80 & 0 \\
\hline Tyrosine & 23 & 13 & 66 & 0 & 0 & 0 & 0 \\
\hline Pigment from tyrosine & 0 & 13 & 66 & 0 & o & 0 & 0 \\
\hline Xanthine & o & 0 & 0 & 40 & I I & 0 & o \\
\hline Starch & 23 & 13 & 66 & 100 & 89 & 20 & 100 \\
\hline Starch (in $10 \% \mathrm{CO}_{2}$ ) & $3 I$ & 25 & 66 & 100 & 78 & 40 & 43 \\
\hline \multicolumn{8}{|l|}{ Sole carbon source } \\
\hline Citrate & I5 & o & 33 & 80 & 33 & 0 & 0 \\
\hline Gluconate & 54 & 38 & 66 & 100 & 89 & 60 & I4 \\
\hline Glucose & 69 & 38 & 100 & 100 & 100 & 100 & 14 \\
\hline Hippurate & 0 & 0 & 0 & 0 & 0 & 0 & 0 \\
\hline Malate & 69 & o & 33 & 80 & 67 & 0 & 14 \\
\hline Propionate & 15 & 0 & 0 & 0 & 0 & 0 & 0 \\
\hline Pyruvate & 38 & 13 & 100 & 80 & 67 & 60 & 14 \\
\hline Succinate & 38 & 0 & 0 & 0 & 44 & 0 & 14 \\
\hline \multicolumn{8}{|l|}{ Sole nitrogen source } \\
\hline$\left(\mathrm{NH}_{4}\right)_{2} \mathrm{SO}_{4}$ & 15 & o & 66 & 100 & 89 & 20 & o \\
\hline $\mathrm{KNO}_{3}$ & 8 & o & 100 & 100 & 78 & 20 & 0 \\
\hline $\mathrm{KNO}_{3}+$ Casamino acid & 54 & 13 & 100 & 100 & 100 & 60 & 43 \\
\hline \multicolumn{8}{|l|}{$\begin{array}{l}\text { Growth in presence of } \\
\mathrm{NaCl}\end{array}$} \\
\hline $5 \%(w / v)$ & 100 & 0 & 33 & 100 & 67 & 100 & 86 \\
\hline $10 \%(w / v)$ & 46 & 0 & 0 & 40 & II & 40 & 29 \\
\hline \multicolumn{8}{|l|}{ Thallous acetate } \\
\hline $0.01 \%(w / v)$ & $3 \mathrm{I}$ & 38 & 33 & 0 & I I & 0 & 29 \\
\hline $0.02 \%(w / v)$ & 0 & 38 & 33 & 0 & 0 & 0 & 29 \\
\hline $0.03 \%(w / v)$ & 0 & 38 & 33 & 0 & 0 & o & 29 \\
\hline \multicolumn{8}{|l|}{ Sodium azide } \\
\hline $0.01 \%(w / v)$ & 46 & 25 & 0 & 0 & 0 & 100 & 0 \\
\hline $0.02 \%(w / v)$ & 8 & 25 & $\circ$ & 0 & 0 & 100 & 0 \\
\hline $0.05 \%(w / v)$ & 0 & 0 & o & 0 & o & 20 & o \\
\hline \multicolumn{8}{|l|}{ Potassium thiocyanate } \\
\hline $2.5 \%(w / v)$ & 92 & 25 & 66 & 100 & 78 & 100 & 100 \\
\hline $3.75 \%(w / v)$ & 62 & 13 & 33 & 100 & 33 & 60 & 100 \\
\hline $4.5 \%(w / v)$ & 46 & 0 & 0 & 100 & I I & 0 & 57 \\
\hline \multicolumn{8}{|l|}{ Tetrazolium } \\
\hline $0.01 \%(w / v)$ & 62 & 38 & o & 100 & 22 & o & 100 \\
\hline Reduction $0.0 \mathrm{I} \%(\mathrm{w} / \mathrm{v})$ & I 8 & 0 & 0 & 40 & 22 & o & 57 \\
\hline $0.1 \%(w / v)$ & 0 & 0 & 0 & 0 & 0 & 0 & 0 \\
\hline Reduction $0.1 \%(w / v)$ & 0 & o & 0 & 0 & o & $\circ$ & o \\
\hline \multicolumn{8}{|l|}{ Potassium tellurite } \\
\hline $0.01 \%(w / v)$ & 100 & 0 & 0 & 40 & 89 & 0 & 43 \\
\hline Reduction $0.0 \mathrm{I} \%(\mathrm{w} / \mathrm{v})$ & 100 & 0 & 0 & 40 & 89 & 0 & 43 \\
\hline $0.025 \%(\mathrm{w} / \mathrm{v})$ & 77 & o & 0 & 20 & 67 & o & 29 \\
\hline Reduction $0.025 \%(\mathrm{w} / \mathrm{v})$ & v) 77 & 0 & 0 & 20 & 67 & 0 & 29 \\
\hline $0.05 \%(w / v)$ & 62 & 0 & 0 & 0 & 44 & 0 & 29 \\
\hline Reduction $0.05 \%(w / v)$ & 62 & 0 & 0 & 0 & 44 & 0 & 29 \\
\hline Lysis by lysozyme & o & 63 & 33 & 100 & 100 & 100 & 100 \\
\hline Lysis by lysozyme + EDTA & o & 63 & 33 & 100 & 100 & 100 & 100 \\
\hline \multicolumn{8}{|l|}{ Sensitivity to $\S$} \\
\hline Penicillin $(\mathrm{H})$ & 100 & 100 & 100 & 40 & 89 & 100 & 86 \\
\hline
\end{tabular}


Table 4 (cont.)

\begin{tabular}{|c|c|c|c|c|c|c|c|}
\hline & $\begin{array}{c}\text { Cor. } \\
\text { diphtheriae } \\
\text { and } \\
\text { related } \\
\text { bacteria } \\
\mathrm{CI}^{*}\end{array}$ & $\begin{array}{c}\text { Cor. } \\
\text { pyogenes } \\
\text { and } \\
\text { related } \\
\text { bacteria } \\
\mathrm{C} 2 * \dagger\end{array}$ & $\begin{array}{c}\text { Micro. } \\
\text { lacticum } \\
\text { Br. } \\
\text { imperiale } \\
\text { D I* }^{*}\end{array}$ & $\begin{array}{c}\text { N. cellulans } \\
\text { N. turbata } \\
\text { D2 } \ddagger\end{array}$ & $\begin{array}{l}\text { Cellulo- } \\
\text { monas } \\
\text { D3* }\end{array}$ & $\begin{array}{c}\text { Propioni- } \\
\text { bacteria } \\
\text { EI }^{*}\end{array}$ & $\begin{array}{c}\text { List. } \\
\text { denitrifi- } \\
\text { cans } \text { and } \\
\text { coryne- } \\
\text { forms } \\
\text { E2 and E3* }\end{array}$ \\
\hline \multicolumn{8}{|l|}{ Sensitivity to (cont.) } \\
\hline Streptomycin $(\mathrm{H})$ & 100 & 100 & 100 & 100 & 100 & 100 & 100 \\
\hline Chloramphenicol $(\mathrm{H})$ & 100 & 100 & 100 & 100 & 100 & 80 & 100 \\
\hline Aureomycin $(\mathrm{H})$ & 100 & 88 & 100 & 100 & 100 & 100 & 100 \\
\hline Terramycin $(\mathbf{H})$ & 100 & 75 & 100 & 100 & 100 & 100 & 100 \\
\hline Erythromycin (H) & 100 & 63 & 100 & 100 & 100 & 80 & 100 \\
\hline Tetracycline $(\mathrm{H})$ & 100 & 50 & 100 & 100 & 100 & 100 & 100 \\
\hline Sulphonamide $(\mathrm{H})$ & 31 & 38 & 0 & 100 & 100 & 40 & 0 \\
\hline Ledermycin $(\mathrm{H})$ & 100 & 100 & 100 & 100 & 100 & 100 & 100 \\
\hline Celbenin & 92 & 75 & 100 & 0 & 22 & 40 & 57 \\
\hline Kanamycin $(\mathrm{H})$ & 100 & 88 & 100 & 100 & 56 & 100 & 100 \\
\hline Penbritin $(\mathrm{H})$ & 92 & 88 & 66 & 100 & 100 & 100 & 100 \\
\hline Spiramycin (L) & 92 & 88 & 100 & 100 & 100 & 100 & 100 \\
\hline Vancomycin (L) & 100 & 100 & 100 & 100 & 100 & 100 & 100 \\
\hline Paromomycin $(\mathrm{H})$ & 92 & 88 & 66 & 100 & 44 & 80 & 100 \\
\hline Fucidin (L) & 100 & 100 & 100 & 100 & 100 & 100 & 100 \\
\hline Neomycin $(\mathrm{H})$ & 100 & 75 & 100 & 100 & 100 & 60 & $\mathcal{E 6}$ \\
\hline Bacitracin & 100 & 100 & 100 & 100 & 100 & 80 & 100 \\
\hline Novobiocin $(\mathrm{H})$ & 92 & 88 & 100 & 100 & 100 & 80 & IOO \\
\hline Oleandomycin $(\mathrm{H})$ & 100 & 88 & 100 & 100 & 100 & 100 & IOO \\
\hline Colomycin (L) & 54 & 75 & 66 & 100 & 89 & 60 & 100 \\
\hline Polymyxin (L) & 92 & 75 & 100 & 100 & 100 & 100 & 100 \\
\hline Nitrofurantoin & 92 & 100 & 33 & 20 & 67 & 80 & 100 \\
\hline Methyl red & 69 & 88 & 100 & 100 & 89 & 100 & 57 \\
\hline Voges Proskauer & 23 & 0 & 33 & 60 & 0 & 40 & 29 \\
\hline Egg yolk ppt & 38 & 50 & 0 & 0 & I I & o & 0 \\
\hline Egg yolk clearing & 15 & 0 & o & 0 & 33 & o & 0 \\
\hline \multicolumn{8}{|l|}{ Litmus milk } \\
\hline Acid production & 23 & 25 & 100 & 100 & 78 & 100 & 43 \\
\hline Alkaline production & $6 I$ & 38 & 0 & 0 & 22 & 0 & 14 \\
\hline Coagulation & 0 & 25 & 0 & 0 & 0 & 40 & 0 \\
\hline Digestion & 0 & 13 & $\circ$ & 0 & 0 & 40 & 0 \\
\hline Peptonization & 8 & 13 & o & 0 & I I & 0 & 0 \\
\hline Reduction & 8 & 0 & 100 & 100 & 22 & 20 & 29 \\
\hline Reduction $\mathrm{NO}_{3} \rightarrow \mathrm{NO}_{2}$ & $3 I$ & 13 & 33 & 100 & 89 & 20 & 71 \\
\hline Reduction $\mathrm{NO}_{3} \rightarrow \mathrm{N}_{2}$ & 0 & 0 & 0 & 0 & 0 & 0 & o \\
\hline Reduction $\mathrm{NO}_{3}$ beyond $\mathrm{N}_{2}$ & 0 & o & 0 & o & 0 & 0 & 0 \\
\hline Production $\mathrm{H}_{2} \mathrm{~S}$ & 38 & 0 & 0 & 0 & I I & 60 & 0 \\
\hline Urease & 30 & 13 & o & 40 & 67 & 0 & I 4 \\
\hline Sulphatase & 0 & 0 & 0 & 0 & 0 & 0 & 0 \\
\hline Phosphatase & 77 & 50 & 100 & 100 & 78 & 60 & I 4 \\
\hline Ammonia from SEB & 69 & 25 & 0 & 0 & I I & 0 & 0 \\
\hline
\end{tabular}

It is isolated from foul brood disease in bees and may well be related to some of the so-called Brevibacterium spp. isolated by Steinhaus (I94I) and Lysenko (I959) from insects. The close association of $\mathrm{Br}$. incertum with this group is in keeping with this hypothesis. However, the appearance of Cor. murium in this loose cluster is perplexing. Its \% GC DNA base ratio $(58 \cdot 5)$ is different from the values of 46 to 48 shown by strains of Cor. pyogenes.

The loose association of Arth. terregens (\% GC, 68.7; Skyring \& Quadling, 1970) and Agr. ramosus with this group throws little light on their true taxonomic position. It does however indicate that they should be removed from the genus Arthrobacter.

Nocardia turbata - Nocardia cellulans. The close grouping of all strains of N. turbata and 
their relationship to $N$. cellulans and Cor. manihot is in agreement with the suggestion that these strains do not belong to the genus Nocardia (LeChevalier \& LeChevalier, 1970; Jones \& Bradley, I 964). Prauser, LeChevalier \& LeChevalier (1970) have proposed that $N$. turbata strains be separated as a new genus Oerskovia in the Actinomycetales. Jones \& Bradley (1964), however, suggested that they should be included in the genus Cellulomonas. The degree of their relationship to Cellulomonas in the present study is probably that of a different genus rather than a species within a genus. However, the $N$. turbata-N. cellulans group falls quite clearly in area II of this study rather than area III which includes the other Nocardia spp.

Cellulomonas. This genus was rationalized by Clark (1951, 1952, 1953) and presently contains ten species (Bergey's Manual of Determinative Bacteriology, 1957). In the present study all representatives grouped as a distinct cluster with the exception of Cel. fimi and Cel. rossica. The Gram reaction of all the species has been inconsistent (Clark, 195 I, I953). In our hands Cel. rossica proved to be Gram-negative but with faint traces of Gram-positive staining (as did a number of soil corynebacteria) but the mode of regulation of its citrate synthase (Jones \& Weitzman, I971) was clearly of the Gram-negative pattern (P. D. J. Weitzman and D. Jones, unpublished).

Doubts have also been expressed on the inclusion of $\mathrm{Cel}$. fimi in the genus Cellulomonas (Jensen, 1934). In the study of Bousfield (1972) Cel. fimi clustered with some Gram-positive 'Flavobacteria'. The results of the present study indicate that it should be reclassified in the genus Arthrobacter.

The main Cellulomonas cluster (D3, Figs. I and 3) merits genus rank quite distinct from the genus Arthrobacter, a conclusion also reached by Yamada \& Komagata $(1972 b)$ on quite different criteria.

Propionibacterium. The close clustering of Propionibacterium species is in agreement with previous numerical studies (Seyfried, 1968; Malik, Reinbold \& Vedamuthu, 1968). The intragroup relationships are in good accord with both these previous studies and also with the DNA homology studies of Johnson \& Cummins (1972) which showed P. shermanii and $P$. freudenreichii to be in the same DNA homology group and $P$. petersonii and $P$. jensenii to be in another one. However, in the present study $P$. pentosaceum shows a close relationship to $P$. petersonii although it fell into a third DNA homology group (Johnson \& Cummins, 1972). This apparent discrepancy is probably the result of the small number of Propionibacterium strains included here.

The lack of any close relationship between Propionibacterium and Lactobacillus confirms the results of Seyfried (1968).

\section{Area III}

Area III is the most heterogeneous of the three major groupings. It contains Arthrobacter, some species of Brevibacterium, Kurthia, and also extends into the Actinomycetales with the inclusion of Mycobacterium and Nocardia. The characteristics of the important taxa are given in Tables 5 and 6.

Arthrobacter. The genus Arthrobacter was created by Conn \& Dimmick (1947) around the type species of Arth. globiformis to accommodate the soil coryneforms which exhibited a rod-coccus 'life cycle'. This life cycle is not confined to Arthrobacter spp., as has also been noted by other workers (see Bousfield, 1972). However, with one or two exceptions all strains received as Arthrobacter clustered with strains received as $\mathrm{Cel}$. fimi and with various named Corynebacterium spp. to form one rather loose taxon containing several distinct groupings (see group F, Figs. I, 2, 3 and 4).

The relationship between Arth. globiformis, Arth.pascens, Arth. ramosus and all the strains 
included as representatives of 'nutrient group A' of Keddie et al. (1966) is in good accord with the classification of these workers based on nutritional requirements.

All representatives of 'nutritional group B' of Keddie et al. (1966), two of their 'nutritional group D' strains, plus nutritional group-intermediate C clustered with Arth. duodecadis, placed by Keddie et al. (I966) in the nutritionally 'ungrouped strains'.

The relationship between Arth. ureafaciens, Arth. aurescens and Cor. ilicis is in agreement with the close association of the latter two species noted by Bousfield (I972) and with the relationship between the first two species noted by Masuo \& Nakagawa (1969) and Davis \& Newton (1969).

Of the remaining Arthrobacter strains, Arth. oxydans appeared distinct and worthy of species status as did Arth. simplex, though the two representatives of the latter species showed a close association with Arth. crystallopoeites. Other clusters which probably merit species status are those groups of strains clustering around Arth. atrocyaneus: Arth. citreus, Arth. tumefaciens, Arth. nicotianeae, Cel. fimi, Cor. michiganense and Cor. rathayi. The last three bacteria should be reclassified as Arthrobacter spp.

Kurthia. The division of Kurthia strains into two clusters, albeit with a high inter-similarity, is in keeping with the reports of Keddie (1943) and Gardner (1969). Four of the strains in this study were also used by Gardner. Kurthia zopfii (NGIB8603), of Gardner's group I, clustered with $\mathrm{K} 2, \mathrm{~s} 8$ and s9, while the representatives of Gardner's group II clustered as a separate group. All seven strains of $K$. zopfii produced $\mathrm{H}_{2} \mathrm{~S}$ from cysteine, though they are reported not to do so from peptone water (Keddie, 1949) and SIM Difco medium (Gardner, I969).

The taxonomic position of Kurthia is problematical. Although clearly in area III, Kurthia was not closely allied to any of the other genera in this area. It has been isolated mainly from milk and meat (see Gardner, 1969) but Keddie (1949) is of the opinion that it is a soil bacterium. There may well be a number of soil bacteria related to Kurthia which have not yet been studied in detail. As stressed by Gardner (1969), the colonial morphology of Kurthia strains resembles that of Micro. thermosphactum. However, the physiological and biochemical reactions of these two taxa are quite different and the apparent relationship between the two noted by Davis \& Newton (1969) was due to the onission from their study of most of the physiological tests. The later study of Davis et al. (1969), which included a broad range of tests, did not show any close affinity between them.

Mycobacterium rhodochrous. The results are in complete agreement with those of other numerical taxonomic studies (Goodfellow, I97I; Goodfellow et al. 1972) which indicate that Myco. rhodochrous, along with a variety of other species, forms a recognizable taxon clearly distinct from the genera Mycobacterium and Nocardia.

Cross \& Goodfellow (1973, Table I6) list a number of named strains which they believe should be allocated to the 'Myco. rhodochrous' complex. These are in good agreement with my results but I would add Arth. variablis and possibly Cor. paurometabolum.

There are at least two main groups in this complex and the heterogeneity of the taxon is in keeping with the results of Bradley (I97I), Goodfellow (I97I) and Goodfellow et al. (1972). The proposal of Tsukamura (1971) that Myco. rhodochrous should be allocated to his new genus Gordona is premature because he studied only six strains of Myco. rhodochrous and none of these was recovered in any of the named species in the genus.

Brevibacterium. As noted by Bousfield (1972) the genus Brevibacterium as presently constituted (Bergey's Manual of Determinative Bacteriology, 1957) does not appear to be a good taxon. Strains received as Brevibacterium spp. are scattered in a number of different clusters in the present study. However, the formation of a distinct cluster by strains of 
Table 5. Characteristics of subgroups $F_{1}, F_{2}, F_{3}, F_{4}$ and $F 5$ as percentages of positive reactions

Information derived from material presented in Figs. 3 and 4.

No. of strains tested

Colonial morphology

Colony elevation flat

Colony elevation raised

Colony elevation convex

Colony elevation irregular

Colony mucoid

Myco.

Colony leaves impression in agar

\begin{tabular}{|c|c|c|c|}
\hline $\begin{array}{c}\text { Kurthia } \\
\qquad F_{I}\end{array}$ & $\begin{array}{c}\text { Brevibacterium } \\
\mathrm{F}_{4}, \mathrm{~F}_{5}\end{array}$ & $\begin{array}{c}\text { Myco. } \\
\text { rhodochrous } \\
\text { F2 }\end{array}$ & $\begin{array}{c}\text { Myco. } \\
\text { rhodochrou } \\
\text { F3 }\end{array}$ \\
\hline 7 & 9 & I 4 & 20 \\
\hline 86 & I I & 0 & 0 \\
\hline 0 & I I & 43 & 0 \\
\hline 14 & 78 & 43 & 90 \\
\hline 0 & 0 & I4 & 10 \\
\hline 0 & 0 & 0 & 50 \\
\hline 100 & 22 & 57 & 90 \\
\hline 0 & 100 & 86 & 90 \\
\hline 100 & 0 & 7 & 10 \\
\hline 100 & 100 & 93 & 85 \\
\hline 0 & 0 & 0 & 15 \\
\hline 0 & I I & 0 & 0 \\
\hline 0 & I I & 64 & 65 \\
\hline 86 & 67 & 29 & 20 \\
\hline 14 & I I & 7 & I 5 \\
\hline 0 & 22 & 64 & 0 \\
\hline 0 & 0 & 0 & 0 \\
\hline 0 & 0 & 7 & 55 \\
\hline 0 & 0 & 7 & IO \\
\hline 0 & 0 & 0 & 0 \\
\hline 71 & 0 & 0 & 5 \\
\hline 29 & 89 & 57 & 95 \\
\hline I4 & II & 29 & I 5 \\
\hline 0 & 0 & $2 \mathrm{I}$ & 45 \\
\hline 0 & 0 & I 4 & I 5 \\
\hline 0 & 0 & 0 & 0 \\
\hline 100 & 22 & 0 & IO \\
\hline 100 & 89 & 86 & 100 \\
\hline 0 & I I & 0 & 0 \\
\hline 0 & 78 & $7 \mathrm{I}$ & 60 \\
\hline 100 & 22 & 29 & 40 \\
\hline 0 & I I & 43 & 45 \\
\hline 100 & 100 & $7 \mathrm{I}$ & 60 \\
\hline 57 & 56 & 93 & 100 \\
\hline IOO & 100 & 100 & 100 \\
\hline 0 & I I & 0 & 0 \\
\hline$\varepsilon 6$ & 89 & $2 \mathrm{I}$ & 65 \\
\hline 86 & 22 & 29 & 25 \\
\hline 0 & 44 & $7 \mathrm{I}$ & 60 \\
\hline $7 \mathrm{I}$ & I I & $2 \mathrm{I}$ & 20 \\
\hline 86 & 100 & 50 & 90 \\
\hline 86 & 100 & 86 & 90 \\
\hline 100 & 100 & 100 & 100 \\
\hline 100 & 100 & 100 & 100 \\
\hline 86 & 22 & 29 & 0 \\
\hline 57 & 0 & 7 & 0 \\
\hline 0 & 0 & 0 & 0 \\
\hline 0 & 22 & 36 & 30 \\
\hline 0 & I I & $7 \mathrm{I}$ & 95 \\
\hline 100 & I00 & 100 & 100 \\
\hline
\end{tabular}

Colony margin entire

Colony margin irregular

Colony easily emulsified

Colony coarse suspension

Colony violet/blue

Colony pink/red

Colony yellow/orange/brown

Colony cream/grey/white

Exopigment, water soluble

Crystals formed

Mycelium formed

Aerial hyphae

Blue/green irridescence

(Henry technique)

Stained preparations

Rods and filaments 7 I

Rods and cocci

Rods only

Branching present

Mycelium present

Cystites

Chains formed

Barred staining

Bipolar staining

Rods $<2 \mu$ m long

Rods $>2 \mu \mathrm{m}$ long

Acid fastness

Homogeneous growth in SEB

Collar/pellicle in SEB

$\beta$-Haemolysis

Greening of blood

Motility

Microcolonies

Flagella

Growth at

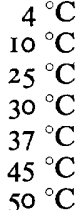

Survival at $60^{\circ} \mathrm{C}$ for $30 \mathrm{~min}$

Anaerobic growth

Catalase
IOO
Myco.

F3

90

10

90

85

55

95

45

I5

00

60

40

60

100

0

65

20

90

100

oo

0

30

100 
Table 5 (cont.)

Benzidine

Oxidase

Acid from

Arabinose

Xylose

Rhamnose

Fructose

Galactose

Glucose

Aerobic

Anaerobic

Mannose

Cellobiose

Lactose

Sucrose

Maltose

Melezitose

Raffinose

Melibiose

Sorbose

Salicin

Adonitol

Inositol

Dulcitol

Mannitol

Glycerol

Sorbitol

Hydrolysis tests

Aesculin blackening

Aesculin loss purple fluorescence

Arginine

Arginine (Thornley)

Casein

Cellulose

Chitin

Gelatin

DNA

Hippurate

Tween 20 clearing

Tween $20 \mathrm{ppt}$

Tween 40 clearing

Tween $40 \mathrm{ppt}$

Tween 60 clearing

Tween $60 \mathrm{ppt}$

Tween 80 clearing

Tween $80 \mathrm{ppt}$

Tyrosine

Pigment from tyrosine

Xanthine

Starch

Starch (in $10 \% \mathrm{CO}_{2}$ )

Sole carbon source

Citrate

Gluconate

Glucose

Hippurate

Malate
Myco.

Kurthia

F I

100

0

o

o

o

o

o

o

o

0

0

o

0

o

o

0

o

0

0

o

0

o

0

57

0

0

I4 II

100

14

0

o

0

I 00

100

0

57

0

I4

100

100
0

0

0

0

0

o

0

Brevibacterium rhodochrous

$$
\mathrm{F}_{4}, \mathrm{~F}_{5}
$$

$\mathrm{F}_{2}$

100

100
78

100
0

Myco.
rhodochrous

$\mathrm{F}_{3}$

78

$0 \quad 0$

7

o

7

o

100

5

o

o

0

10

5

IO

I4

7

14

14

0

7 
Table 5 (cont.)

Sole carbon source (cont.)

Propionate

Pyruvate

Succinate

Sole nitrogen source

$\left(\mathrm{NH}_{4}\right)_{2} \mathrm{SO}_{4}$

$\mathrm{KNO}_{3}$

$\mathrm{KNO}_{3}+$ Casamino acid

Growth in presence of

$\mathrm{NaCl}$

$5 \%(w / v)$

$10 \%(w / v)$

Thallous acetate

$0.01 \%(w / v)$

$0.02 \%(w / v)$

$0.03 \%(\mathrm{w} / \mathrm{v})$

Sodium azide

$0.01 \%(w / v)$

$0.02 \%(w / v)$

$0.05 \%(\mathrm{w} / \mathrm{v})$

Potassium thiocyanate

$2.5 \%(\mathrm{w} / \mathrm{v})$

$3.75 \%(w / v)$

$4.5 \%(\mathrm{w} / \mathrm{v})$

Tetrazolium

$0.01 \%(\mathrm{w} / \mathrm{v})$

Reduction $0.01 \%(w / v)$

$0.1 \%(w / v)$

Reduction $0.1 \%(w / v)$

Kurthia Brevibacterium rhodochrous

$\begin{array}{ccc}\text { Kurthia } & \text { Brevibacterium } & \text { rhodochrous } \\ \mathrm{FI}_{1} & \mathrm{~F}_{4}, \mathrm{~F}_{5} & \mathrm{~F}_{2}\end{array}$

Myco.

rhodochrous

$\begin{array}{rrrr}0 & 44 & 0 & 0 \\ \text { I4 } & 56 & 7 & 35 \\ 0 & 11 & 0 & 5 \\ 0 & 67 & 100 & 100 \\ 0 & 67 & 100 & 100 \\ 71 & 89 & 100 & 100\end{array}$

IOO

100

$100 \quad 100$

$\begin{array}{llll}49 & 100 & 57 & 25\end{array}$

7 I

$43 \quad 40$

43

22

30

0

2 I

25

$29 \quad 33$

I4

F3

Potassium tellurite

$0.01 \%(w / v)$

Reduction $0.01 \%(w / v)$

$0.025 \%(w / v)$

Reduction $0.025 \%(\mathrm{w} / \mathrm{v})$

$0.05 \%(w / v)$

Reduction $0.05 \%(w / v)$

Lysis by lysozyme

Lysis by lysozyme + EDTA

0

o

43

50

$29-35$

33

22

I 5

IOO

100

100

100

95

100

57

100

93

95

IOO

56

93

95

100

0
0

86

100

861100

64

100
65

I 4

65

$71 \quad 89$

100

100

100

100

100

100

100

I00

90

90

90

90

25

7 I

2 I

45

Sensitivity to*

Penicillin (H)

Streptomycin $(\mathbf{H})$

Chloramphenicol (H)

Aureomycin (H)

Terramycin $(\mathbf{H})$

Erythromycin $(\mathrm{H})$

Tetracycline $(\mathrm{H})$

Sulphonamide $(\mathrm{H})$

Ledermycin (H)

Celbenin

Kanamycin (H)

Penbritin (H)

Spiramycin (L)

100

29

95

$100 \quad 100$

I00

$\begin{array}{ll}100 & 100 \\ 100 & 100\end{array}$

79

100

$100 \quad 100$

100

100

100

100

100

100

100

IOO

IOO

95

100

100

100

IOO

65

I00

56

2 I

100

7

I0O

roo

100
22

$100 \quad 100$

$100 \quad 100$

I00 II

IOO IOO

Vancomycin (L)

Paromomycin (H)

Fucidin (L)

Neomycin $(\mathrm{H})$

100

100

100

IOO

100

0

100

100

100

95

93
100

100

100

100

80

100

100

* (H), high potency; (L), low potency. 
Table 5 (cont.)

\begin{tabular}{|c|c|c|c|c|}
\hline \multirow{2}{*}{\multicolumn{5}{|c|}{ Sensitivity to (cont.) }} \\
\hline & & & & \\
\hline Bacitracin & 100 & 100 & 100 & 100 \\
\hline Novobiocin $(\mathrm{H})$ & 100 & I I & 100 & 95 \\
\hline Oleandomycin $(\mathrm{H})$ & 100 & 100 & IOO & 100 \\
\hline Colomycin (L) & 86 & 100 & 100 & 35 \\
\hline Polymyxin (L) & 100 & 100 & 100 & 100 \\
\hline Nitrofurantoin & 100 & 33 & 100 & 100 \\
\hline Methyl red & 0 & 0 & 0 & 0 \\
\hline Voges Proskauer & o & II & 0 & o \\
\hline Egg yolk ppt & 0 & o & 7 & 0 \\
\hline Egg yolk clearing & o & o & 0 & o \\
\hline \multicolumn{5}{|l|}{ Litmus milk } \\
\hline Acid production & o & o & 0 & 0 \\
\hline Alkaline production & 100 & 100 & 100 & 100 \\
\hline Coagulation & o & 0 & 0 & o \\
\hline Digestion & 0 & 0 & 0 & 0 \\
\hline Peptonization & I 4 & 22 & 0 & 10 \\
\hline Reduction & 57 & o & 0 & IO \\
\hline Reduction $\mathrm{NO}_{3} \rightarrow \mathrm{NO}_{2}$ & 0 & 33 & 57 & 40 \\
\hline Reduction $\mathrm{NO}_{3} \rightarrow \mathrm{N}_{2}$ & o & 0 & 0 & 0 \\
\hline Reduction $\mathrm{NO}_{3}$ beyond $\mathrm{N}_{2}$ & 0 & o & 0 & 0 \\
\hline Production $\mathrm{H}_{2} \mathrm{~S}$ & 86 & 89 & 100 & 95 \\
\hline Urease & o & 56 & 79 & 90 \\
\hline Sulphatase & o & II & 0 & o \\
\hline Phosphatase & $7 \mathrm{I}$ & 100 & 100 & 100 \\
\hline Ammonia from SEB & 100 & 78 & 86 & 95 \\
\hline
\end{tabular}

$B$. linens, the type species, and the association with this group of $B$. ammoniogenes and $B$. stationis lends support to the case made for the retention of the name Brevibacterium but with an emended description as suggested by Yamada \& Komagata (1972 $b$ ).

The three strains received as Corynebacterium and Arthrobacter, which grouped with the two $B$. linens strains to form a tight cluster ( $\mathrm{F}_{4}$, see Figs. 2 and 4 ), all contained a carotenoidlike material which appears to be characteristic of $B$. linens strains (Jones, Watkins \& Erikson, I973). The position of NCIB8I79 in this cluster, however, is not easily explained. This bacterium was deposited as Pseudomonas iodinum, but was considered by Sneath (I960) to be either a Corynebacterium or a Brevibacterium and was reclassified by Colwell, Citarella, Ryman \& Chapman ( 1969) as Arth. iodinum. All attempts to demonstrate the presence of the $B r$. linens carotenoid-like material failed. It is possible that it is a carotenoid-less mutant but it would additionally have had to develop the purple crystals of iodinin.

Mycobacterium and Nocardia. With the exception of N. cellulans, N. calcarea, N. opaca and $N$. turbata, all the Nocardia strains clustered together.

Because so few Mycobacterium strains were included, little can be said about the relationship of the two taxa. The grouping of the Mycobacterium strains with Nocardia spp. (see Figs. 2 and 4 ) is probably due both to this and to the fact that the tests chosen were more suitable for differentiation in the corynebacteria-arthrobacter area.

Plant pathogenic corynebacteria. The Corynebacterium spp. from plant sources did not group as one cluster. All (with the exception of Cor. insidiosum which was placed as a satellite strain between areas I and II) clustered in area III.

The results indicate that Cor. fascians should be reclassified in the 'Myco. rhodochrous' 


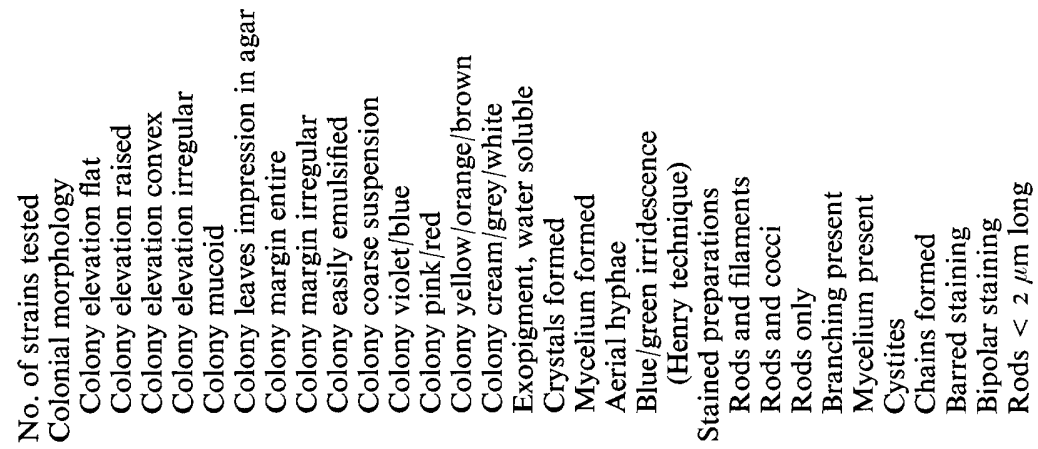




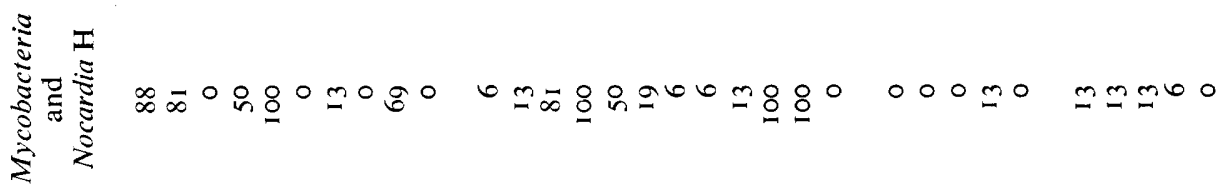

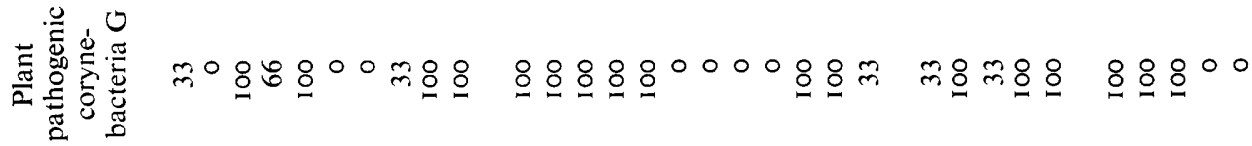
竎 离

= nomㅁำ 亏ั)

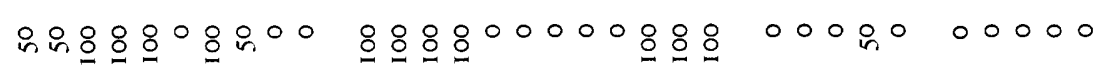
紊文

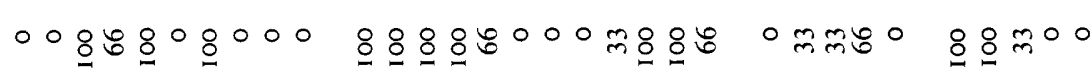
离

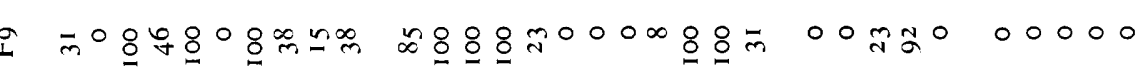

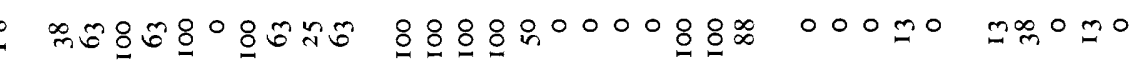

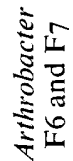

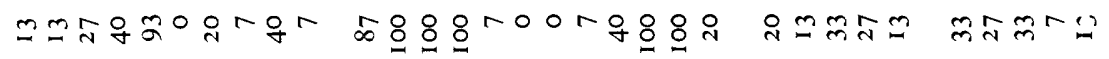

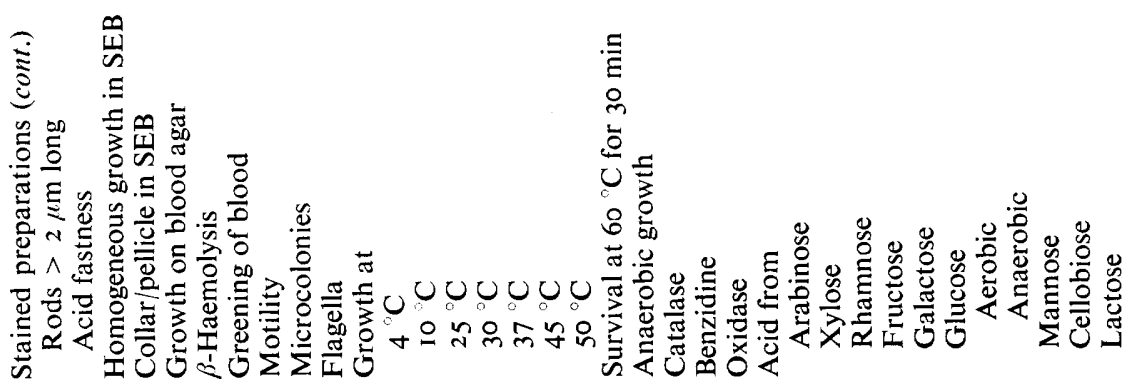




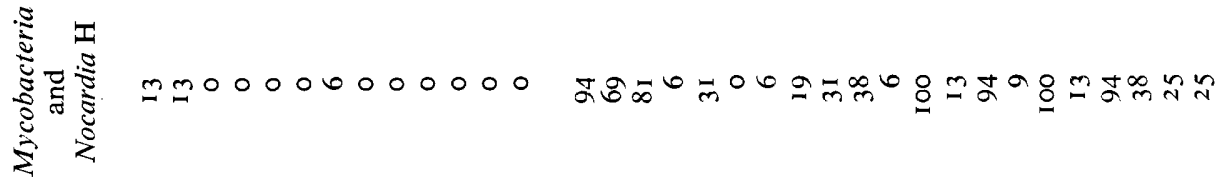

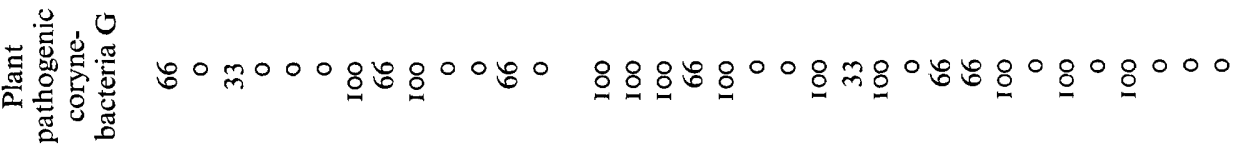

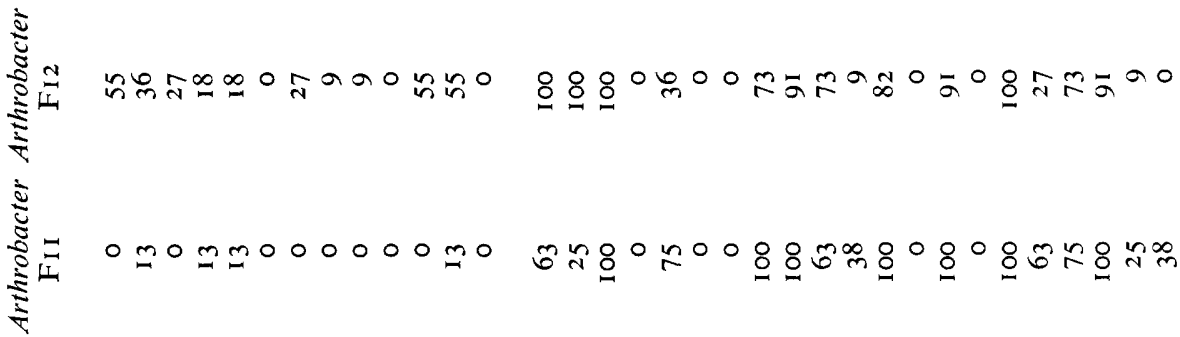

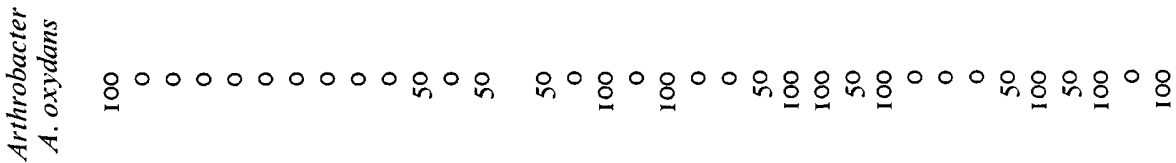

$800000000080 \mathrm{~m} 8.80000883808088 \% 800$ (ั)

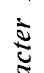

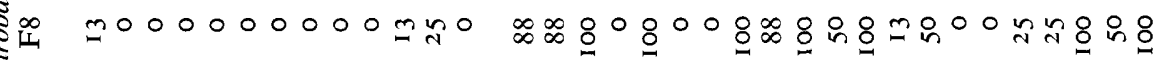
竞 竎畜

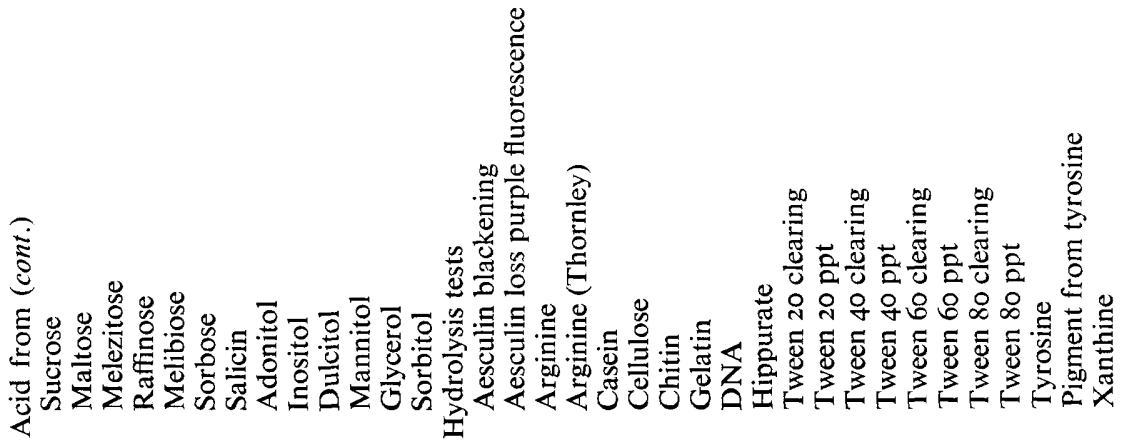




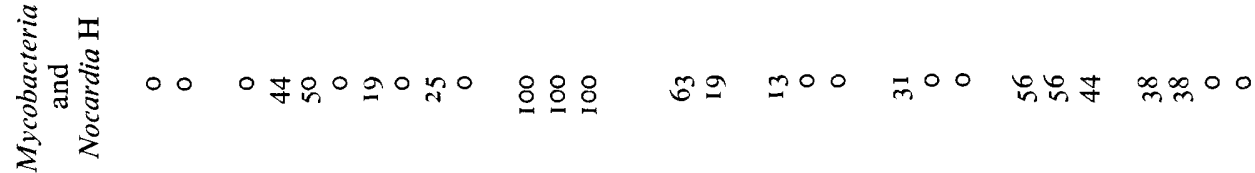

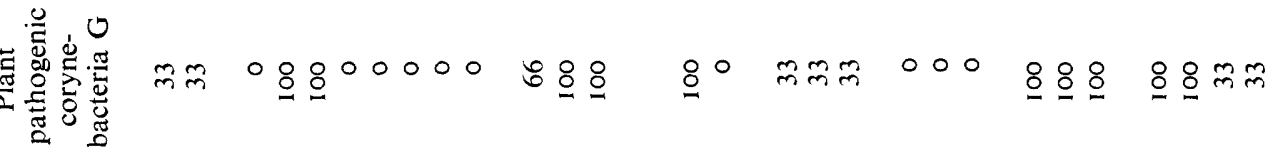

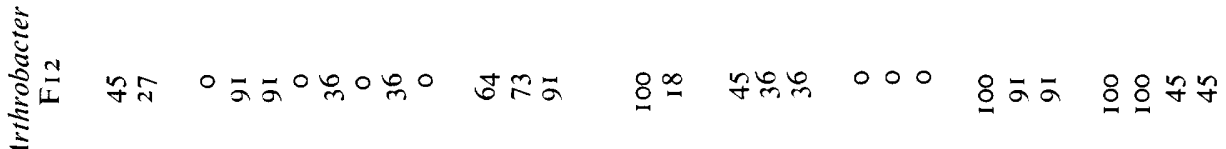
育竎 密章

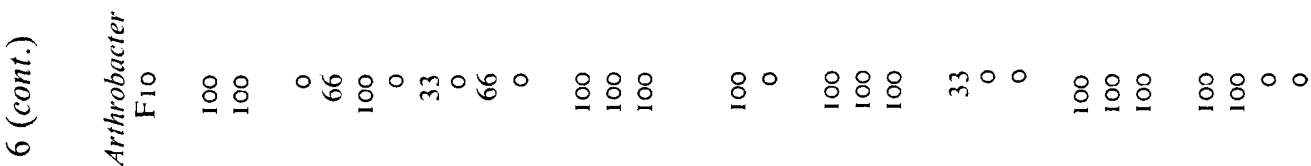
苋勻 离地

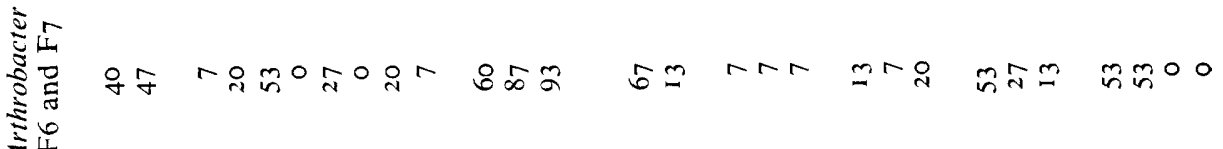

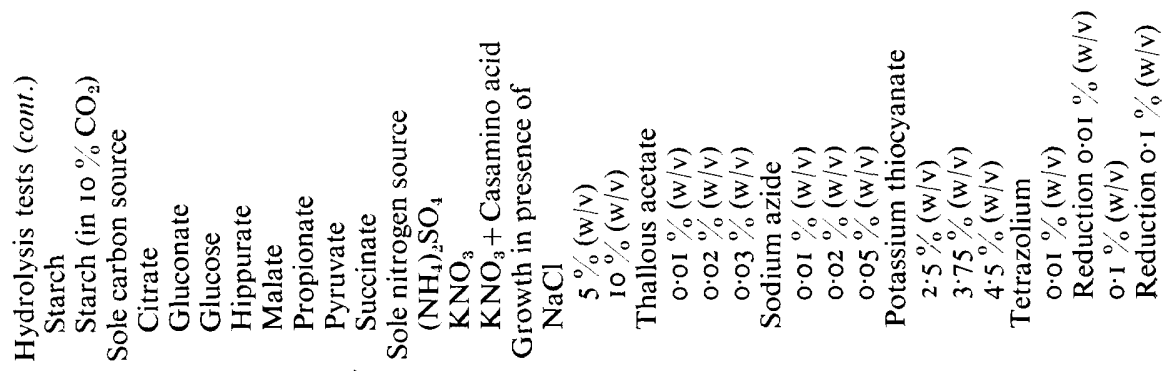




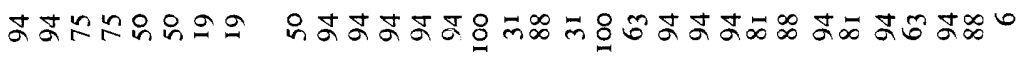

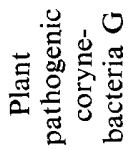

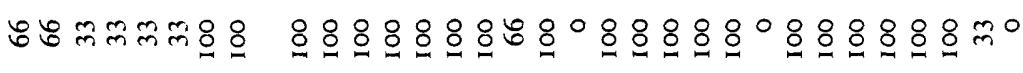
竞

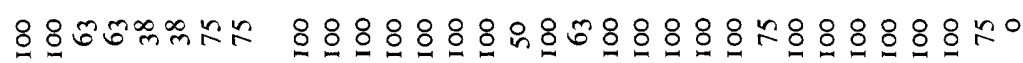

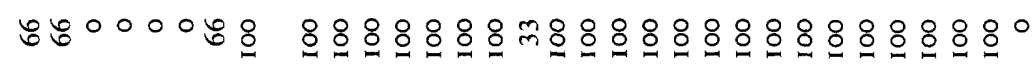

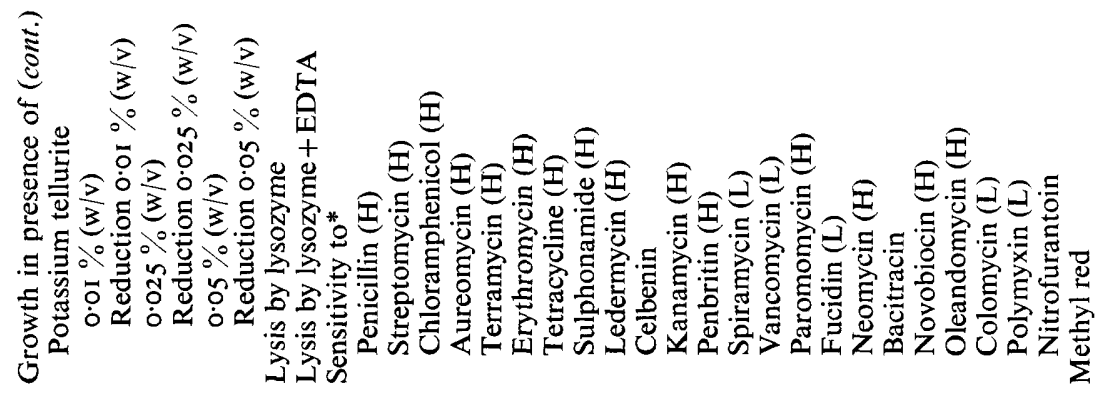




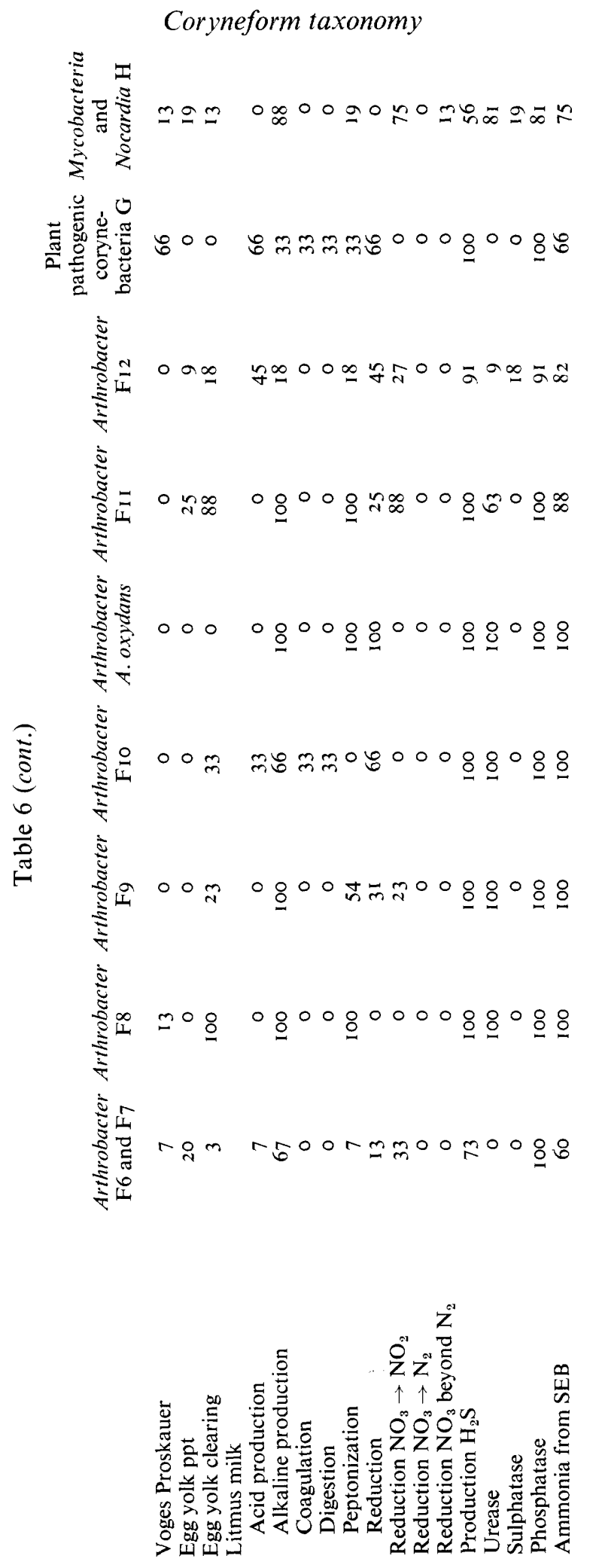


area. Corynebacterium ilicis, Cor. michigenense and Cor. rathayi should be reclassified as Arthrobacter spp. This is in agreement with the observation of Lelliott (1966) that Cor. fascians was probably more closely related to Nocardia and with his findings that Cor. fascians and Cor. ilicis were the only urease-positive members of the group. Similarly Lacey (1955) reported branching and acid-fast nocardia-like cells in the Cor. fascians and Cor. michigenense strains studied by him.

Rosenthal \& Cox (1953) showed a serological relationship between Cor. michigenense and Cor. insidiosum. This relationship was not confirmed in the present study. However, only one strain of Cor. michigenense was included and there do seem to be marked serological differences between different strains of this species (Lelliott, I966).

The close serological similarity between Cor. poinsettiae and Cor. flaccumfaciens noted by Rosenthal \& Cox (I954) and the relationship between both these species and Cor. betae suggested by Lelliott (I966) is confirmed in the present study. However, my results indicate that all should be removed from the genus Corynebacterium. Yamada \& Komagata (I972 $b$ ) have proposed a new genus Curtobacterium (type species Curtobacterium citreum) to include certain motile brevibacteria, Cor.flaccumfaciens and Cor.poinsettiae, and my results indicate that Cor. betae may also be placed here.

Ungrouped strains. Brevibacterium leucinophagum (Kinney \& Werkman, I960), appeared Gram-negative, with traces of Gram-positive staining. However, enzyme studies showed it to be a Gram-negative bacterium probably of the genus Acinetobacter (Jones \& Weitzman, 1974). This is in keeping with its position in the present study.

Cellulomonas rossica - Corynebacterium nephridii. These two strains also gave equivocal Gram reactions. Clark (I95I) was of the opinion that Cel. rossica was Gram-negative and in a later paper (Clark, 1952) he recommended its exclusion from the genus Cellulomonas. There appears to be little work on Cor. nephridii. Unpublished work (P. D. J. Weitzman and D. Jones) indicates that the citrate synthases of both these bacteria have the regulatory properties typical of those found in Gram-negative bacteria.

Brevibacterium acetylicum, Achromobacter liquefaciens. These two strains group in area III and show about an $85 \%$ similarity to each other. Both give weak but definite Grampositive staining reactions and both possess citrate synthase with the regulatory properties of Gram-positive bacteria (Jones \& Weitzman, 197I). Little can be said about their taxonomic position.

\section{CONCLUSIONS}

As pointed out by Sneath (1972) there is a growing opinion that categories above the rank of species and genus are artificial in bacteriology, but nevertheless they are convenient for referring to groups of related bacteria for purposes of presentation.

In a study of this kind, comprising such diverse bacterial genera, it seems sensible to attempt to summarize the main conclusions and as far as possible indicate the relationships of bacteria in the context of the higher taxa (families) as presently listed in Bergey's Manual of Determinative Bacteriology (1957).

I. The genera Erysipelothrix and Listeria and the species Micro. thermosphactum should be removed from the Corynebacteriaceae. A strong case can be made for their inclusion in the family Lactobacillaceae. Microbacterium thermosphactum is sufficiently distinct to merit genus status. The characters which differentiate the three species are given in Table 7.

2. The family Corynebacteriaceae contains at least five and probably six taxa worthy of genus rank: (i) a group synonymous with Corynebacterium (Lehmann \& Neumann) containing Cor. diphtheriae and related animal bacteria and Micro. flavum, but not Cor. equi, 
Table 7. Characters which differentiate M. thermosphactum, L. monocytogenes and E. rhusiopathiae

Tests

Growth at $37^{\circ} \mathrm{C}$

Growth at $4{ }^{\circ} \mathrm{C}$

Colonial appearance

'Fried egg colony'

'Henry technique'

$\beta$-Haemolysis

Greening on blood

Catalase

Motility

Growth in presence of

$\mathrm{NaCl}(5 \%)$

$\mathrm{NaCl}(10 \%)$

$\mathrm{Na}$ azide (0.0I \%)

K. thiocyanate $(2 \cdot 5 \%)$

K. thiocyanate $(3 \cdot 75 \%)$

Reduction of

K. tellurite $(0.01 \%)$

K. tellurite $(0.25 \%)$

Tetrazolium $(0.01 \%)$

Hydrolysis of

Tween 40

Tween 60

Sodium hippurate

Phosphatase

Lysis by lysozyme

Sensitivity to

Kanamycin

Neomycin

Novobiocin

Voges/Proskauer

Acid from

Adonitol

Arabinose

Cellobiose

Dulcitol

Glycerol

Inositol

Mannitol

Melibiose

Rhamnose

Salicin

Sorbitol

Sucrose

Growth on gluconate
Micro. thermosphactum

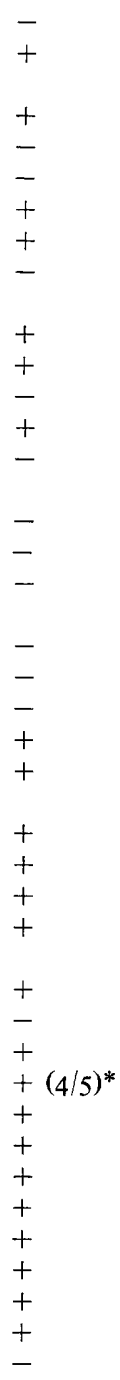

List. monocytogenes

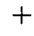

$+$

$-$

$+$

$+$

$-$

+
+

$+$

$+$

$+$

$-$

$+$

$+(19 / 21)^{*}$

$+$

$+(17 / 2 I)^{*}$

$+$

$+$

$+$

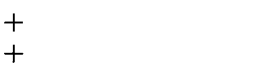

$+$

$+$

\section{$-$}

$+$

$+$

$+$

$-(19 / 21)^{*}$

-

$-$

$+$

$+(\mathrm{Ig} / 2 \mathrm{I})^{*}$

$+$

$+$
E. rhusiopathiae

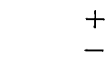

weak +

$+$

* No. of strains giving reaction, out of total tested.

Cor. haemolyticum, Cor. pyogenes or Cor. murium; (ii) a group clustering around Cor. pyogenes; (iii) Cellulomonas (Clark, 1952) but excluding Cel. fimi which should be reclassified as Arth. fimi; (iv) Propionibacterium; (v) a group based on List. denitrificans and strains isolated from other sources; (vi) Microbacterium (Orla-Jensen, 19I9), excluding Micro. flavum and Micro. thermosphactum but including strains now referred to as Br. imperiale.

3. The genus Arthrobacter should be removed from the family Corynebacteriaceae as it shows a closer affinity to area III than to area II. It is a large heterogeneous taxon. Cellulo- 
monas fimi, Cor. aquaticum, Cor. ilicis, Cor. michiganense, Cor. rathayi, Cor. vesiculare and Cor. viscosum should be reclassified as Arthrobacter species.

4. Brevibacterium should be retained for the species Br. linens, Br. ammoniogenes and Br. stationis. Kurthia is a distinct group of bacteria and there is no evidence to support its inclusion with Brevibacterium in the family Brevibacteriaceae.

5. Bacteria named 'Mycobacterium rhodochrous' together with Arth. variabilis, Cor. equi, Cor. fascians, Jensenia canicruria, N. calcared, N. opaca and possibly Cor. paurometabolum form a distinct taxon separate from the genera Mycrobacterium and Nocardia. There is evidence for at least two clear-cut groupings worthy of generic rank.

6. The plant pathogenic corynebacteria should be removed from the genus Corynebacterium.

7. Nocardia cellulans and N. turbata should be removed from the genus Nocardia. The genus Oerskovia (Prauser et al. 1970) has been proposed for this group and our results support separate genus status distinct from the genus Cellulomonas. They group in area II and could be placed in the Corynebacteriaceae.

The results of this study indicate that bacteria presently called 'coryneform' can be allocated to at least three different families. The work presented here provides some clarification of the problems and highlights those areas where further study is required. The relationships which emerge are in good accord with other numerical taxonomic studies of smaller samples of the same bacterial genera and with chemotaxonomic studies.

I thank Professor P. H. A. Sneath for his keen interest in this work. I am indebted to Mr John Watkins for skilled technical assistance and to Mr M. Sackin for his help with the computation.

\section{REFERENCES}

AbD-EL-MALEK, Y. \& Gibson, T. (I952). Studies in the bacteriology of milk. III. The corynebacteria of milk. Journal of Dairy Research 19, 153-159.

Abe, S., TAKayama, K. \& Kinoshita, S. (1967). Taxonomical studies on glutamic acid producing bacteria. Journal of General and Applied Microbiology 13, 279-301.

BAlLEY, L. (1957). The isolation and cultural characteristics of Streptococcus pluton (Bacillus pluton White) and further observations on Bacterium eurydice White. Journal of General Microbiology 17, 39-48.

BAILEY, L. (1960). The epizootiology of European foul brood of the larval honey bee, Apis mellifera Linnaeus. Journal of Insect Pathology 2, 67-83.

BAILEY, L. (1963). The habitat of Bacterium eurydice. Journal of General Microbiology 31, I47-I 50.

BARKSDALE, L. (1970). Corynebacterium diphtheriae and its relatives. Bacteriological Reviews 34, 378-422.

Barksdale, W. L., Li, K., Cưmins, C. S. \& Harris, H. (1957). The mutation of Corynebacterium pyogenes to Corynebacterium haemolyticum. Journal of General Microbiology 16, 749-758.

Bergey's Manual of Determinative Bacterlology, 7th edn (I957). Edited by R. S. Breed, E. G. D. Murray and R. N. Smith. London: Baillière, Tindall \& Cox.

Bouisset, L., Breuillard, J. \& Michel, G. (1963). Étude de l'ADN chez les Actinomycetales. Annales de l'Institut Pasteur ro4, 756-770.

Bousfield, I. J. (1972). A taxonomic study of some coryneform bacteria. Journal of General Microbiology $7 \mathrm{I}, 44 \mathrm{I}-455$.

Bowie, I. S., Grigor, M. R., Dunckley, G. G., Loutit, M. W. \& Loutit, J. S. (I972). The DNA base composition and fatty acid constitution of some Gram-positive pleomorphic soil bacteria. Soil Biology and Biochemistry 4, 397-4I 2.

Bradley, S. G. (I97I). Criteria for definition of Mycobacterium, Nocardia and the rhodochrous complex. Advancing Frontiers of Plant Science 28, 349-367.

Chatelain, R. \& Second, L. (I966). Taxonomie numérique de quelques Brevibacterium. Annales del'Institut Pasteur III, 630-644.

Clark, F. E. (195I). The generic classification of certain cellulolytic bacteria. Soil Science Society American Proceedings 15, I80-182. 
CLARK, F. E. (1952). The generic classification of the soil corynebacteria. International Bulletin of Bacteriological Nomenclature and Taxonomy 2, 45-56.

Clark, F. E. (1953). Criteria suitable for species differentiation in Cellulomonas and a revision of the genus. International Bulletin of Bacteriological Nomenclature and Taxonomy 3, 179-199.

Collins-Thompson, D. L., Sørhaug, T., Witter, L. D. \& Ordal, Z. J. (I972). Taxonomic consideration of Microbacterium lacticum, Microbacterium flavum and Microbacterium thermosphactum. International Journal of Systematic Bacteriology 22, 65-72.

Colwell, R. R., Citarella, R. V., Ryman, I. \& Chapman, G. B. (1969). Properties of Pseudomonas iodinum. Canadian Journal of Microbiology $\mathbf{1 5}, 85 \mathrm{I}-857$.

ConN, H. J. \& Dimmick, I. (1947). Soil bacteria similar in morphology to Mycobacterium and Corynebacterium. Journal of Bacteriology 54, 29I-303.

CowAN, S. T. \& SteEL, K. T. (I965). Manual for the Identification of Medical Bacteria. Cambridge: Cambridge University Press.

Cross, T. \& Goodfellow, M. (1973). Taxonomy and classification of the actinomycetes. In Actinomycetales, Characteristics and Practical Importance. Society for Applied Bacteriology Symposium Series No. 2. London: Academic Press.

Cummins, C. S. \& Harris, H. (1956). The chemical composition of the cell wall in some Gram-positive bacteria and its possible value as a taxonomic character. Journal of General Microbiology 14, 583600.

CURE, G. L. \& KedDIE, R. M. (1972). Methods for the morphological examination of aerobic corynebacteria. In Sampling - Microbiological Monitoring of Environments, Society for Applied Bacteriology Technical Series 7, pp. I23-135. Edited by R. G. Board and D. W. Lovelock. New York and London: Academic Press.

Dacre, J. C. \& Sharpe, M. E. (1956). Catalase production by lactobacilli. Nature, London $\mathbf{7 8 8 ,} 700$.

Da Silva, G. A. N. \& Holt, J. G. (1965). Numerical taxonomy of certain coryneform bacteria. Journal of Bacteriology 90, 92 I-927.

Davidson, C. M., MobBs, P. \& StubBs, J. M. (1968). Some morphological and physiological properties of Microbacterium thermosphactum. Journal of Applied Bacteriology 3I, 55 I-559.

Davis, G. H. G. (1955). The classification of lactobacilli from the human mouth. Journal of General Microbiology I3, 48I-493.

Davis, G. H. G., Fomin, L., Wilson, E. \& Newton, K. G. (I969). Numerical taxonomy of Listeria, streptococci and possibly related bacteria. Journal of General Microbiology 57, 333-348.

Davis, G. H. G. \& Newton, K. G. (1969). Numerical taxonomy of some named coryneform bacteria. Journal of General Microbiology 56, 195-2 I4.

Deibel, R. H. \& Evans, J. B. (I960). Modified benzidine test for the detection of cytochrome containing respiratory systems in microorganisms. Journal of Bacteriology 79, 356-360.

Di Salvo, J. W. (1958). Deoxyribonuclease and coagulase activity of micrococci. Medical Technology Bulletin 9, I9I-I 96.

FlossmanN, K.-D. \& ERLER, W. (1972). Serologische, chemische und immunochemische Untersuchungen an Rotlaufbakterien. XI. Isolierung und Charakterisierung von Deoxyribonukleinsäuren aus Rotlaufbakterien. Archiv für experimentelle Veterinärmedizin 26, 81 7-824.

GaRDNER, G. A. (1969). Physiological and morphological characteristics of Kurthia zopfii isolated from meat products. Journal of Applied Bacteriology 32, 37 I-380.

Grison, T. (1953). Taxonomy of the genus Corynebacterium. In Proceedings of 6th International Congress of Microbiology, Rome, vol. I, pp. I 6-20.

GoodfelLow, M. (1971). Numerical taxonomy of some nocardioform bacteria. Journal of General Microbiology 69, 33-80.

Goodfellow, M., Fleming, A. \& SACKIN, M. J. (1972). Numerical classification of 'Mycobacterium' rhodochrous and Runyon's group IV mycobacteria. International Journal of Systematic Bacteriology 22, $8 \mathrm{I}-98$.

Goodfellow, M., Minnikin, D. E., Patel, P. V. \& Mordarska, H. (1973). Free nocardomycolic acids in the classification of nocardias and strains of the 'rhodochrous' complex. Journal of General Microbiology 74, I85-188.

Gordon, R. E. \& Miнм, J. M. (1957). A comparative study of some strains received as nocardiae. Journal of Bacteriology 73, I5-27.

HarRington, B. J. (I966). Numerical taxonomical study of some corynebacteria and related organisms. Journal of General Microbiology 45, 3I-40.

HenRy, B. S. (1933). Dissociation in the genus Brucella. Journal of Infectious Diseases 52, 374-402. 
HUGH, R. \& Leifson, E. (1953). The taxonomic significance of the fermentative versus oxidative metabolism of carbohydrates by various Gram-negative bacteria. Journal of Bacteriology 66, 24-26.

Jensen, H. L. (1932). Contributions to our knowledge of the Actinomycetales. IV. The identity of certain species of Mycobacterium and Proactinomyces. Proceedings of the Linnean Society of New South Wales $57,364-367$.

Jensen, H. L. (1933). Corynebacteria as an important group of soil microorganisms. Proceedings of the Linnean Society of New South Wales 58, $181-185$.

JENSEN, H. L. (1934). Studies on the saprophytic mycobacteria and corynebacteria. Proceedings of the Linnean Society of New South Wales 59, 19-61.

JenSEN, H. L. (1952). The coryneform bacteria. Annual Review of Microbiology 6, 77-9o.

JENSEN, H. L. (1966). Some introductory remarks on the coryneform bacteria. Journal of Applied Bacteriology 29, $13-16$.

Johnson, J. L. \& Cummins, C. S. (1972). Cell wall composition and deoxyribonucleic acid similarities among the anerobic coryneforms, classical propionibacteria and strains of Arachnia propionica. Journal of Bacteriology 109, 1047-1066.

Jones, D., WAtKins, J. \& MeYer, D. J. (I970). Cytochrome composition and effect of catalase on growth of Agromyces ramosus. Nature, London 226, 1249-1250.

Jones, D., WatKins, J. \& Erikson, S. K. (I973). Taxonomically significant colour changes in Brevibacterium linens probably associated with a carotenoid-like pigment. Journal of General Microbiology 77, I45-150.

Jones, D. \& Weitzman, P. D. J. (197I). Taxonomic significance of citrate synthase. Journal of General Microbiology 69, xi.

Jones, D. \& WeITZMan, P. D. J. (1974). Reclassification of Brevibacterium leucinophagum Kinney \& Werkman as a Gram-negative organism, probably in the genus Acinetobacter. International Journal of Systematic Bacteriology 24, II 3-117.

Jones, L. A. \& BradLey, S. G. (I964). Phenetic classification of actinomycetes. Development in Industrial Microbiology 5, 267-272.

KedDIE, R. M. (1949). A study of Bacterium zopfii Kurth. Dissertation, Edinburgh School of Agriculture.

Keddie, R. M., Leask, B. G. S. \& Grainger, J. M. (1966). A comparison of coryneform bacteria from soil and herbage: cell wall composition and nutrition. Journal of Applied Bacteriology 29, 17-43.

KINNEY, R. W. \& WERKMAN, C. H. (1960). Brevibacterium leucinophagum spec. nov. International Bulletin of Bacteriological Nomenclature and Taxonomy 10, $213-217$.

KLinge, K. (1960). Differential techniques and methods of isolation of Pseudomonas. Journal of Applied Bacteriology 23, 442-462.

Komagata, K., Yamada, K. \& Ogawa, H. (1969). Taxonomic studies on coryneform bacteria. I. Division of bacterial cells. Journal of General and Applied Microbiology 15, 243-25I.

LACEY, M. S. (1955). The cytology and relationships of Corynebacterium fascians. Transactions of the British Mycological Society 38, 49-58.

LeChevalier, H. A. \& LeChevalier, M. P. (1970). A critical evaluation of the genera of aerobic actinomycetes. In The Actinomycetales, pp. 393-405. Edited by H. Prauser. Jena: Gustav Fischer.

LelliotT, R. A. (I966). The plant pathogenic coryneform bacteria. Journal of Applied Bacteriology 29, I I4II 8.

LochHeAd, A. G. \& Burton, M. O. (1956). The incidence in the soil of bacteria requiring vitamin $B_{12}$ and the terregens factor. Soil Science 82, 237-245.

LYSENKo, O. (1959). The occurrence of species of the genus Brevibacterium in insects. Journal of Insect Pathology 1, 34-42.

Malik, A. C., Reinbold, G. W. \& Vedamuthu, E. R. (1968). An evaluation of the taxonomy of Propionibacterium. Canadian Journal of Microbiology $\mathbf{1 4}$, I I 85-I I9I.

MASUO, E. \& NAKAGAWA, T. (1969). Numerical classification of bacteria. II. Computer analysis of coryneform bacteria: comparison of group formations obtained on two different methods of scoring data. Agricultural and Biological Chemistry 33, I $124-\mathrm{I} 133$.

Melville, T. H. (1965). A study of the overall similarity of certain actinomycetes mainly of oral origin. Journal of General Microbiology 40, 309-3I 5.

Metcalf, R. H. \& Deibel, R. H. (I969). Differential lytic response of enterococci associated with addition order of lysozyme and anions. Journal of Bacteriology 99, 674-680.

Modarska, H., Modarski, M. \& Goodfellow, M. (I972). Chemotaxonomic characters and classification of some nocardioform bacteria. Journal of General Microbiology 7r; $77-86$.

Mullakhanbhai, M. F. \& Bhat, J. V. (1967). A numerical taxonomical study of Arthrobacter. Current Science 36, II5-II8. 
OWENS, J. D. \& KeDDIE, R. M. (1969). Nitrogen nutrition of soil and herbage coryneform bacteria. Journal of Applied Bacteriology 32, 338--347.

Orla-Jensen, S. (1919). The Lactic Acid Bacteria. Copenhagen: Andr. Fred. Host \& Son.

Prauser, H., LeChevalier, M. P. \& LeChevalier, H. (1970). Description of Oerskovia gen. n. to harbor Ørskov's motile Nocardia. Applied Microbiology 19, 534.

Rhodes, M. E. (1958). The cytology of Pseudomonas spp. as revealed by a silver-plating staining method. Journal of General Microbiology 18, 639-648.

ROBERTS, R. J. (1968). Biochemical reactions of Corynebacterium pyogenes. Journal of Pathology and Bacteriology $95, \mathrm{I} 27-\mathrm{I} 30$.

Robinson, K. (1966a). An examination of Corynebacterium species by gel electrophoresis. Journal of Applied Bacteriology 29, 179-I 84 .

Robinson, K. (1966 b). Some observations on the taxonomy of the genus Microbacterium. I. Cultural and physiological reactions and heat resistance. Journal of Applied Bacteriology 29, 607-615.

Robinson, K. (I $966 c$ ). Some observations on the taxonomy of the genus Microbacterium. II. Cell wall analysis, gel electrophoresis and serology. Journal of Applied Bacteriology 29, 61 6-624.

Rosenthal, S. A. \& Cox, C. D. (1953). The somatic antigens of Corynebacterium michiganense and Corynebacterium insidiosum. Journal of Bacteriology 65, 532-537.

Rosenthal, S. A. \& Cox, C. D. (I954). An antigenic analysis of some plant and soil corynebacteria. Phytopathology 44, 603-613.

SCHEFferle, H. E. (I966). Coryneform bacteria in poultry deep litter. Journal of Applied Bacteriology 29, 147-I60.

SCHLEIFER, K. H.(1970). Die Mureintypen der Gattung Micrabacterium. Archiv für Mikrobiologie 7r, 27 I-282.

SEYFRIED, P. L. (1968). An approach to the classification of lactobacilli using computer aided numerical analysis. Canadian Journal of Microbiology 14, 31 3-318.

SKERMAN, V. B. D. (1967). A Guide to the Identification of the Genera of Bacteria, 2nd edn. Baltimore, Williams and Wilkins.

Skyring, G. W. \& QuAdling, C. (1970). Soil bacteria: principle component analysis and guanine-cytosine contents of some arthrobacter-coryneform soil isolates and of some named cultures. Canadian Journal of Microbiology $\mathbf{1 6}, 95-106$.

SNeAth, P. H. A. (1957). The application of computers to taxonomy. Journal of General Microbiology $\mathbf{1 7}$, $20 \mathrm{I}-226$.

SNEATh, P. H. A. (1960). A study of the bacterial genus Chromobacterinm. Iowa State Journal of Science $\mathbf{3 4}$, $243-500$.

Sneath, P. H. A. (I966). Identification methods applied to Chromobacterium. In Identification Methods for Microbiologists, Part A. Edited by B. M. Gibbs and F. A. Skinner. London: Academic Press.

Sneath, P. H. A. (1972). Computer taxonomy. In Methods in Microbiology, vol. 7A, pp. 29-98. Edited by J. R. Norris and D. W. Ribbons. London: Academic Press.

SNEATh, P. H. A. \& Cowan, S. T. (1958). An electro-taxonomic survey of bacteria. Journal of General Microbiology 19, 55I-565.

SNeAth, P. H. A. \& Johnson, R. (1972). The influence on numerical taxonomic similarities of errors in microbiological tests. Journal of General Microbiology 72, 377-392.

Sneath, P. H. A. \& Stevens, M. (1967). A divided Petri dish for use with multipoint inoculators. Journal of Applied Bacteriology 3o, 495-497.

Sokal, R. R. \& Michener, C. D. (I958). A statistical method for evaluating systematic relationships. Kansas University Science Bulletin 38, I409-1438.

Splitstoesser, D. E., Wexler, M., White, J. \& Colwell, R. R. (I967). Numerical taxonomy of Grampositive and catalase-positive rods isolated from frozen vegetables. Applied Microbiology r5, 158162.

Steinhaus, E. A. (I94I). A study of the bacteria associated with thirty species of insects. Journal of Bacteri$\operatorname{olog} y \mathbf{4 2}, 747-790$.

Stevens, M. (1969). Development and use of multi-inoculation test methods for a taxonomic study. Journal of Medical Laboratory Technology 26, 253-263.

Stuart, M. R. \& Pease, P. E. (1972). A numerical study of the relationships of Listeria and Erysipelothrix. Journal of General Microbiology 73, 55I-565.

Stuart, S. E. \& Welshimer, H. J. (1973). Intrageneric relatedness of Listeria Pirie. International Journal of Systematic Bacteriology 23, 8-14.

Thornley, M.J. (1960). The differentiation of Pseudomonas from other Gram-negative bacteria on the basis of arginine metabolism. Journal of Applied Bacteriology 23, 37-52. 
ThorNLEy, M. J. \& SharPe, M. E. (I959). Micro-organisms from chicken meat related to both lactobacilli and aerobic sporeformers. Journal of Applied Bacteriology 22, 368-376.

ToppiNG, L. E. (1937). The predominant microorganisms in soils. I. Description and classification of the organisms. Zentralblatt für Bakteriologie, Parasitenkunde, Infektionskrankheiten und Hygeine (Abteilung II) 97, 289-304.

TrivetT, T. L. \& Meyer, E. A. (1971). Citrate cycle and related metabolism of Listeria monocytogenes. Journal of Bacteriology 107, 770-779.

Tsukamura, M. (197I). Proposal of a new genus, Gordona, for slightly acid-fast organisms occurring in sputa of patients with pulmonary disease and in soil. Journal of General Microbiology 68, i 5-26.

Vanderzant, C., Jưdins, P. W., Nickelson, R. \& Fitshugh, H. A. (1972). Numerical taxonomy of coryneform bacteria isolated from pond-reared shrimp (Penaeus azetecus) and pond water. Applied Microbiology 23, 38-45.

VANKova, J. (I957). Motile catalase-producing strains of Lactobacillus. Nature, London I79, 204.

VeldKamp, H. (1970). Saprophytic coryneform bacteria. Annual Review of Microbiology 24, 209-240.

WhitTENBURY, R. (1964). Hydrogen peroxide formation and catalase activity in the lactic acid bacteria. Journal of General Microbiology 35, 13-26.

WILKINSON, B. J. (1973). A numerical taxonomic and serological study of Listeria and possibly related bacteria. Ph.D. Thesis, University of Leicester.

Wilson, G. S. \& Miles, A. A. (1964). Topley \& Wilson's Principles of Bacteriology and Immunity, vol. I, 5 th edn. London: Arnold.

WooD, D. (1969). Isolation of Listeria monocytogenes. In Isolation Methods for Microbiologists, Society for Applied Bacteriology Technical Series 3, pp. 63-69. Edited by D. A. Shapton and G. W. Gould. New York and London: Academic Press.

Yamada, K. \& Komagata, K. (1968). Taxonomic studies on coryneform bacteria. In International Conference of Culture Collections Tokyo (abstr.), p. 23. Tokyo: University of Tokyo Press.

Yamada, K. \& Komagata, K. (I970a). Taxonomic studies on coryneform bacteria. Ir. Principal amino acids in the cell wall and their taxonomic significance. Journal of General and Applied Microbiology I6, I03-II3.

Yamada, K. \& Komagata, K. (1970 $b$ ). Taxonomic studies on coryneform bacteria. III. DNA base composition of coryneform bacteria. Journal of General and Applied Microbiology 16, 21 5-224.

Yamada, K. \& KomaGata, K. (I972a). Taxonomic studies on coryneform bacteria. IV. Morphological, cultural, biochemical and physiological characteristics. Journal of General and Applied Microbiology I8, 399-4I6.

Yamada, K. \& Komagata, K. (1972 b). Taxonomic studies on coryneform bacteria. V. Classification of coryneform bacteria. Journal of General and Applied Microbiology 18, 4I7-43I. 